\title{
Analysis of nucleation events in the European boundary layer using the regional aerosol-climate model REMO-HAM with a solar radiation-driven $\mathrm{OH}-$ proxy
}

\author{
J.-P. Pietikäinen ${ }^{1}$, S. Mikkonen ${ }^{2}$, A. Hamed ${ }^{2, \dagger}$, A. I. Hienola ${ }^{1}$, W. Birmili ${ }^{3}$, M. Kulmala ${ }^{4}$, and A. Laaksonen ${ }^{1,2}$ \\ ${ }^{1}$ Finnish Meteorological Institute, P. O. Box 503, 00101 Helsinki, Finland \\ ${ }^{2}$ Department of Applied Physics, University of Eastern Finland, P. O. Box 1627, 70211 Kuopio, Finland \\ ${ }^{3}$ Leibniz Institute for Tropospheric Research (IfT), Permoserstr. 15, 04318 Leipzig, Germany \\ ${ }^{4}$ Department of Physics, University of Helsinki, P. O. Box 44, 00014 Helsinki, Finland \\ ${ }^{\dagger}$ deceased in September 2013
}

Correspondence to: J.-P. Pietikäinen (joni-pekka.pietikainen@fmi.fi)

Received: 13 January 2014 - Published in Atmos. Chem. Phys. Discuss.: 2 April 2014

Revised: 12 September 2014 - Accepted: 22 September 2014 - Published: 7 November 2014

\begin{abstract}
This work describes improvements in the regional aerosol-climate model REMO-HAM in order to simulate more realistically the process of atmospheric new particle formation (NPF). A new scheme was implemented to simulate $\mathrm{OH}$ radical concentrations using a proxy approach based on observations and also accounting for the effects of clouds upon $\mathrm{OH}$ concentrations. Second, the nucleation rate calculation was modified to directly simulate the formation rates of $3 \mathrm{~nm}$ particles, which removes some unnecessary steps in the formation rate calculations used earlier in the model. Using the updated model version, NPF over Europe was simulated for the periods 2003-2004 and 2008-2009. The statistics of the simulated particle formation events were subsequently compared to observations from 13 ground-based measurement sites. The new model shows improved agreement with the observed NPF rates compared to former versions and can simulate the event statistics realistically for most parts of Europe.
\end{abstract}

\section{Introduction}

Atmospheric aerosols influence our quality of life in many different ways, from affecting human health and diminishing visibility, to changing the climate patterns and the hydrological cycle. An important phenomenon associated with the atmospheric aerosol system is the formation of new aerosol particles through gas-to-particle conversion, a process that seems to occur almost everywhere in the troposphere (Kulmala et al., 2004). The climate relevance of new particle formation has been demonstrated in several studies (e.g. Spracklen et al., 2006; Wang and Penner, 2009; Matsui et al., 2011). NPF strongly influences aerosol number concentrations and makes an important contribution to global and local cloud condensation nuclei (CCN) concentrations (Lihavainen et al., 2003; Kerminen et al., 2005; Laaksonen et al., 2005; Merikanto et al., 2009). As such, nucleation is among the key processes that need to be represented in stateof-the-art regional and global aerosol-climate models.

Modelling nucleation and the subsequent growth is a difficult task. Based on the assumption that sulfuric acid $\left(\mathrm{H}_{2} \mathrm{SO}_{4}\right)$ is the main driving force in the process of nucleation, several parametrizations have been proposed to explain NPF: binary water-sulfuric acid nucleation (Vehkamäki et al., 2002), ternary water-sulfuric acid-ammonia nucleation (Napari et al., 2002; Merikanto et al., 2007), ion-induced nucleation involving water and sulfuric acid (Modgil et al., 2005), an ion-mediated nucleation (IMN) mechanism (Yu, 2010) and combined neutral and ion-induced nucleation (Kazil and Lovejoy, 2007), as well as two nucleation parametrizations for the forested boundary layer (BL) - the cluster activation mechanism (Kulmala et al., 2006; Sihto et al., 2006) and the kinetic mechanism (Laakso et al., 2004; Kuang et al., 2008). These parametrizations are designed to estimate the number 
of nucleated particles as a function of the main controlling parameter $\left(\mathrm{H}_{2} \mathrm{SO}_{4}\right)$ at the expense of compromising the realism of the simulated process. For example, Metzger et al. (2010) showed that using the product of the concentrations of $\mathrm{H}_{2} \mathrm{SO}_{4}$ and organic molecules, the modelled nucleation rates were in better accord with measured values.

The ability of global and regional models to predict NPF events has been tested before. Spracklen et al. (2008) used a global chemistry transport model with aerosol microphysics to predict the contribution of boundary layer nucleation to regional and global distributions of CCN. They found that by using the cluster activation scheme, the modelled particle size distributions and total particle number concentrations at three continental sites in Europe were improved. Makkonen et al. (2009) modified a global aerosolclimate model with respect to NPF by including several optional nucleation parametrizations that could be run together with binary homogeneous sulfuric acid-water nucleation. By adding the cluster activation parametrization to the boundary layer, the authors found that the particle number concentration in the lower atmosphere increased more than 10fold, while in the upper atmosphere the increase was even larger. The study also showed that the cloud droplet number concentration depends on the nucleation mechanism used. Kazil et al. (2010) implemented a new scheme for neutral and ion-induced nucleation of sulfuric acid and water in a global aerosol-climate model, considering that such a nucleation mechanism is a good candidate to explain NPF over the oceans and free troposphere. The combination of the new scheme and nucleation via cluster activation seemed to better explain the observations of ultrafine aerosol concentrations over the Pacific Ocean than the cluster activation alone.

Many other studies using global aerosol-climate models have demonstrated the importance of atmospheric NPF for regional and global aerosol number concentration and cloud condensation nuclei budgets (Merikanto et al., 2009; Pierce et al., 2007; Pierce and Adams, 2009; Wang and Penner, 2009; Yu and Luo, 2009; Trivitayanurak et al., 2008; Jung et al., 2010; Laakso et al., 2013; Scott et al., 2014), each study assessing which parametrization leads to the best agreement with observations in their model. Global models have a large grid size (usually $200-300 \mathrm{~km}$ when aerosols are included), hence the number concentration of newly formed particles and size distribution are prone to large uncertainties. Regional climate models, on the other hand, have resolution varying from kilometres to tens of kilometres and hence resolve much greater variability in emissions and processing, and provide a better framework to calibrate potential nucleation mechanisms against observations.

Numerous regional climate models exist, but only a few have been used to analyse NPF. Sotiropoulou et al. (2006) used an air quality model based gas/aerosol model to study the impact of NPF on regional air quality and $\mathrm{CCN}$ formation. They concluded that an online coupled regional aerosol-climate model would improve the nucleation analy- sis done in their work. Matsui et al. (2011) used a weather research and forecasting model coupled with chemistry to study NPF over the Beijing region in China. The authors showed that the model is able to reproduce the timing of NPF events and non-NPF days. Matsui et al. (2011) reported that reductions in primary aerosol emissions do not necessarily lead to lower CCN concentrations because NPF generates a stronger source of $\mathrm{CCN}$ in conditions with lower condensation sink. Fountoukis et al. (2012) used a three dimensional chemical transport model with a microphysical module to simulate NPF on the European scale. They showed that in some regions the total particle number concentrations can be increased by a factor of 3 when nucleation is included. They also found that a semi-empirical ternary sulfuric acid-ammonia-water parametrization shows better agreement with measurements of particles larger than $10 \mathrm{~nm}$ than kinetic or activation parametrization.

In this study, the predictive capability of the NPF of the regional aerosol-climate model REMO-HAM is investigated. The results are compared with measurements from 13 European sites covering years 2003-2004 and 2008-2009, which allows us to test the nucleation in the model against the observations covering a range of seasons and environments. REMO-HAM is modified in this work to include a new measurement-based $\mathrm{OH}$-proxy. The advantage thereof is that the incoming solar radiation is linked to the $\mathrm{OH}$ concentrations, thus taking into account the effects of clouds. The method shown here can be very useful for other types of models where nucleation is important to resolve adequately, but for whom a tropospheric chemistry scheme would be prohibitively expensive. In addition, the particle formation rate of $\sim 1 \mathrm{~nm}$ clusters is replaced by the direct formation of $3 \mathrm{~nm}$ particles. This study is (to our knowledge) the first to compare nucleation rates from the model to those from observations. In the previous studies, the focus has been in comparing simulated and measured particle concentrations. Comparing the model nucleation rate against that derived from the observations is a stronger constraint than comparing particle concentrations to observed particle concentrations, because the latter has greater possibility for compensating errors (for example via biases in coagulation sink or particle growth rates).

The paper is structured as follows: first, the models with their modifications and the methods are described in Sect. 2; Sect. 3 presents a detailed analysis of the results, followed by Sect. 4, where the main conclusions are listed and further steps are discussed. 


\section{Methods}

\subsection{Model description}

\subsubsection{ECHAM5-HAM global aerosol-climate model}

In this work, the updated version ECHAM5-HAM2 (Roeckner et al., 2003; Stier et al., 2005; Zhang et al., 2012) is used to provide lateral aerosol boundary data for the regional model simulations. ECHAM-HAM2 is a global aerosolclimate model that includes the updated HAM2 aerosol module (Stier et al., 2005; Zhang et al., 2012) and the microphysical module M7 (Vignati et al., 2004).

\subsubsection{REMO-HAM regional aerosol-climate model}

In this study, the main tool is the regional aerosol-climate model REMO-HAM (Pietikäinen et al., 2012). The core of REMO-HAM is a hydrostatic, three-dimensional atmosphere model developed at the Max Planck Institute for Meteorology in Hamburg, and is based on the Europa Model, the former numerical weather prediction model of the German Weather Service (Jacob and Podzun, 1996; Jacob, 2001). The physical core of REMO is based on the physical packages of the global circulation model ECHAM4 (Roeckner et al., 1996). Many parts of the model, for example the cloud and soil treatments, have been updated (Pfeifer, 2003; Semmler et al., 2004; Hagemann, 2002; Rechid, 2009; Kotlarski, 2007). With respect to the aerosol module, REMO-HAM incorporates many of the updates in physics that are included in the recent ECHAM5-HAM2 version (REMO-HAM has the HAM suffix because it does not have all the HAM2 updates). The main deficiencies of REMO-HAM are the missing SOA module and the online coupling of the HAM module with the radiation scheme (Pietikäinen et al., 2012).

\subsection{OH-proxy}

The chemistry modules of ECHAM-HAM and REMO-HAM are based on a sulfate aerosol chemistry module described by Feichter et al. (1996). In this module, dimethyl sulfide (DMS), sulfur dioxide $\left(\mathrm{SO}_{2}\right)$ and sulfate $\left(\mathrm{SO}_{4}^{2-}\right)$ are treated as prognostic variables. For oxidation, the module uses three-dimensional monthly mean oxidant fields from hydroxyl $(\mathrm{OH})$, hydrogen peroxide $\left(\mathrm{H}_{2} \mathrm{O}_{2}\right)$, ozone $\left(\mathrm{O}_{3}\right)$ and nitrogen dioxide $\left(\mathrm{NO}_{2}\right)$ (Stier et al., 2005). These fields are calculated/provided by the comprehensive MOZART chemical transport model (Horowitz et al., 2003). Both gas- and aqueous-phase oxidations are included. In the gas phase, $\mathrm{SO}_{2}$ and DMS are oxidized by $\mathrm{OH}$ during the day time while DMS reacts with the nitrate radical $\left(\mathrm{NO}_{3}\right)$ during the night. $\mathrm{NO}_{3}$ is assumed to be in steady state with its production and loss terms, which both include reactions with $\mathrm{NO}_{2}$. The reactions of $\mathrm{O}_{3}, \mathrm{SO}_{2}$ and $\mathrm{H}_{2} \mathrm{O}_{2}$ are considered in the aqueous phase.
The formation of sulfuric acid $\left(\mathrm{H}_{2} \mathrm{SO}_{4}\right)$ occurs via the reaction between the hydroxyl radical $\mathrm{OH}$ and sulfur dioxide $\mathrm{SO}_{2}$; which, in turn, is directly emitted from various anthropogenic and natural sources. $\mathrm{SO}_{2}$ is also produced in a reaction between DMS and $\mathrm{OH}$. The $\mathrm{OH}$ concentrations are higher during the day time due to photolysis reactions (source terms) (Seinfeld and Pandis, 1998). As mentioned before, the models use monthly mean fields for $\mathrm{OH}$, which is not a very realistic approach. To overcome this problem, both ECHAM-HAM and REMO-HAM use an artificial diurnal cycle. This is obtained by using the monthly mean values as a baseline and multiplying them with a diurnal coefficient. This coefficient follows a cosine peak between sunrise and sunset and its amplitude is scaled with the day length (thus, the monthly mean values for $\mathrm{OH}$ are preserved). Although this approach is more realistic than the original, where the constant values were used, it has some disadvantages: it can overestimate the values for short days, and it is not connected to radiation (for example, below clouds, the concentrations are not affected by the decreased solar radiation).

In order to preserve the speed of the chemical module (keep it as usable as possible for long-term simulations), the calculation method for $\mathrm{OH}$ concentrations is replaced with an $\mathrm{OH}$-proxy. Rohrer and Berresheim (2006) presented an equation for approximating $\mathrm{OH}$ concentration by using a nonlinear function of the photolysis frequency of ozone $J\left(\mathrm{O}^{1} \mathrm{D}\right)$ as a predictor. The approach is to build the proxy by using variables that are commonly measured in different sites and can be easily accessed with atmospheric models. Thus, the downward short-wave flux (SWF $\downarrow$ ) is used as the main predictor instead of $J\left(\mathrm{O}^{1} \mathrm{D}\right)$. The reasons for this are that the correlation between these two variables is evident, SWF $\downarrow$ is often measured, and SWF $\downarrow$ is available in the climate models. The construction of the proxy follows a similar approach to that used by Mikkonen et al. (2011) for $\mathrm{H}_{2} \mathrm{SO}_{4}$ concentration. A nonlinear fitting procedure is applied to the measurement data, where the functional form for the proxy is given by

$[\mathrm{OH}]=a \times(\mathrm{SWF} \downarrow)^{b}+c$,

where the exponent $b$ reflects the combined effects of all photolytic processes that generate $\mathrm{OH}$ either directly or via production of and recycling from $\mathrm{HO}_{2}$. The dependence of $\mathrm{OH}$ on reactants such as $\mathrm{NO}_{\mathrm{x}}$, hydrocarbons, $\mathrm{O}_{3}$ or $\mathrm{H}_{2} \mathrm{O}$ is condensed into the single pre-exponential coefficient, $a$. The coefficient $c$ includes all processes that are light-independent; for example, $\mathrm{OH}$ production at night time. These coefficients were estimated with $\mathrm{OH}$-measurement data recorded in Hyytiälä, Finland (Petäjä et al., 2009).

The implemented OH-proxy $\left(\mathrm{OH}_{\text {proxy }}\right)$ is

$\mathrm{OH}_{\text {proxy }}= \begin{cases}3081.0 \cdot(\mathrm{SWF} \downarrow)^{0.8397} & \text { day time } \\ 6.033 \times 10^{4} & \text { night time, }\end{cases}$

where the units are $\left[\right.$ molec $\left.\mathrm{cm}^{-3}\right]$ for OH-proxy and $\left[\mathrm{W} \mathrm{m}^{-2}\right.$ ] for $\mathrm{SWF} \downarrow$. With this approach, the $\mathrm{OH}$ concentrations used 
by the model are more realistic and are linked to the incoming solar radiation in each grid box on every model level.

\subsection{Nucleation scheme}

ECHAM-HAM and REMO-HAM use a binary sulfuric acidwater nucleation scheme by Vehkamäki et al. (2002) and a neutral and charged $\mathrm{H}_{2} \mathrm{SO}_{4} / \mathrm{H}_{2} \mathrm{O}$ nucleation scheme by Kazil and Lovejoy (2007) along with two nucleation mechanisms restricted to the forested boundary layer: the cluster activation (Kulmala et al., 2006) and the kinetic nucleation scheme (Laakso et al., 2004). These empirical schemes are usually employed to calculate the formation rates of 1 (or 1.5) nm clusters. However, the empirical formulae are not based on directly measured cluster formation rates, as the $1 \mathrm{~nm}$ rates have been obtained by extrapolation from measured $3 \mathrm{~nm}$ particle formation rates (Kerminen and Kulmala, 2002). The extrapolation requires, as input, the cluster growth rate, which often has quite large uncertainty. Furthermore, condensable organics (Kulmala et al., 2013), which are known to participate in cluster growth between 1 and $3 \mathrm{~nm}$, are not included in the current model setup. Taken together, the extrapolation from $3 \mathrm{~nm}$ to $1 \mathrm{~nm}$ and the modelling of the growth from $1 \mathrm{~nm}$ back to $3 \mathrm{~nm}$ creates an error in the modelled $3 \mathrm{~nm}$ particle formation rates. This unnecessary calculation cycle can be bypassed as the $3 \mathrm{~nm}$ formation rate can be directly parametrized based on observations.

In this work, the formation rate of $3 \mathrm{~nm}$ particles $J_{3 \mathrm{~nm}}$ $\left[\mathrm{cm}^{-3} \mathrm{~s}^{-1}\right]$ is calculated using the kinetic nucleation scheme

$J_{3 \mathrm{~nm}}=K \times\left[\mathrm{H}_{2} \mathrm{SO}_{4}\right]^{2}$,

where $K=1.417 \times 10^{-15}\left[\mathrm{~cm}^{3} \mathrm{~s}^{-1}\right]$ is the kinetic coefficient and $\left[\mathrm{H}_{2} \mathrm{SO}_{4}\right]$ is the sulfuric acid concentration in molec $\mathrm{cm}^{-3}$. The value of the kinetic coefficient, $K$, is based on a comparison of the model results and measurements conducted within this work (not shown). We compared measured $\mathrm{H}_{2} \mathrm{SO}_{4}$ concentrations against different $K$ values from Hyytiälä, Melpitz and San Pietro Capofiume, and derived the best fit. The $3 \mathrm{~nm}$ particles are assumed to consist of sulfuric acid only (and thus a corresponding amount of $\mathrm{H}_{2} \mathrm{SO}_{4}$ is removed from the gas phase as the particles are formed).

The default approach of nucleation rate is also modified: kinetic nucleation is not restricted to occur only at the forested boundary layer, but is instead calculated in every grid box. As the nucleation mechanism(s) at higher altitudes are unknown, this approach may generate some error. However, our focus is on boundary layer nucleation, and therefore our conclusions are more or less independent of the assumed free tropospheric nucleation mechanism.

\subsection{Simulations}

The ECHAM5-HAM data are used at the lateral boundaries of REMO-HAM (Pietikäinen et al., 2012) for aerosol species

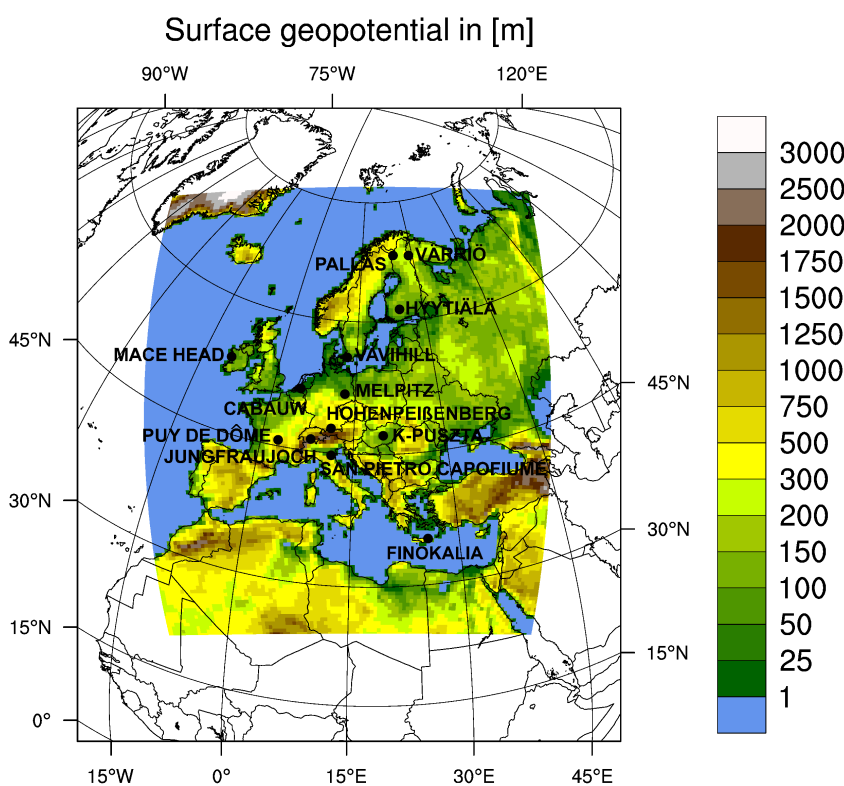

Figure 1. The orography of the REMO domain and the analysed locations.

with an update frequency of $6 \mathrm{~h}$. ERA-Interim data are used to nudge ECHAM5-HAM and as a lateral meteorological boundary forcing for REMO-HAM (Dee et al., 2011). The resolution of T63L31 is applied for ECHAM5-HAM (horizontally $210 \mathrm{~km}$, vertically 31 levels), while for REMOHAM a resolution of $0.44^{\circ}(50 \mathrm{~km} \times 50 \mathrm{~km})$ is used with 27 vertical levels. The models have been run for the years 2003-2004 and 2008-2009 with spin-up times of 3 months. The domain for REMO-HAM covers the whole of Europe. To study the nucleation events in more detail, one-hour output resolution for the REMO-HAM simulations is used. For 2003 and 2004, two model versions are used: OH-proxy version including $3 \mathrm{~nm}$ nucleation in all grid boxes (henceforth called REMO-OHP), and a normal chemistry version including $3 \mathrm{~nm}$ nucleation in all grid boxes (henceforth called REMO-NCH).

Figure 1 shows the orography of the model domain and the measurement sites used in this study. Detailed information about the measurement sites is presented in Table 1.

\subsection{Measurement sites and data}

Two different approaches for comparing the simulated nucleation events against measurement data are used. Firstly, observation data from three stations, Hyytiälä, Melpitz and San Pietro Capofiume, are used. Details about measurement data and instruments used can be found in Birmili and Wiedensohler (2000); Jaatinen et al. (2009) and Engler et al. (2007). The aerosol size distributions, from which the event statistics were calculated, were measured using a twin Differential Mobility Particle Sizer (DMPS) at all sites. Secondly, literature-based observation data are used to analyse the 
Table 1. Measurement sites with long-term observations of the new particle formation events analysed in this work.

\begin{tabular}{|c|c|c|c|c|}
\hline Observation site & Coordinates & $\begin{array}{l}\text { Altitude } \\
\text { (ma.s.l.) }\end{array}$ & Measurement period & Reference \\
\hline Hyytiälä, Finland & $61^{\circ} 50^{\prime} \mathrm{N}, 24^{\circ} 18^{\prime} \mathrm{E}$ & 181 & $\begin{array}{l}1 \text { Jan 2003-31 Dec } 2004 \\
\text { Mar 2008-Apr } 2009\end{array}$ & $\begin{array}{l}\text { Hari and Kulmala (2005) } \\
\text { Manninen et al. (2010) }\end{array}$ \\
\hline Melpitz, Germany & $51^{\circ} 32^{\prime} \mathrm{N}, 12^{\circ} 54^{\prime} \mathrm{E}$ & 87 & $\begin{array}{l}1 \text { Jul 2003-31 Dec } 2004 \\
\text { May 2008-Apr } 2009\end{array}$ & $\begin{array}{l}\text { Birmili and Wiedensohler (2000) } \\
\text { Engler et al. (2007) } \\
\text { Manninen et al. (2010) }\end{array}$ \\
\hline San Pietro Capofiume, Italy & $44^{\circ} 37^{\prime} \mathrm{N}, 11^{\circ} 40^{\prime} \mathrm{E}$ & 11 & $\begin{array}{l}\text { 2003-Aug } 2004 \text { (partly Oct) } \\
\text { Mar 2008-Sep } 2008\end{array}$ & $\begin{array}{l}\text { Jaatinen et al. (2009) } \\
\text { Manninen et al. (2010) }\end{array}$ \\
\hline Mace Head, Ireland & $53^{\circ} 19^{\prime} \mathrm{N}, 09^{\circ} 53^{\prime} \mathrm{E}$ & 5 & $\begin{array}{l}\text { Aug 2002-Jul } 2004 \\
\text { Jun 2008-Apr } 2009\end{array}$ & $\begin{array}{l}\text { Yoon et al. (2006) } \\
\text { Manninen et al. (2010) }\end{array}$ \\
\hline Hohenpeißenberg, Germany & $47^{\circ} 48^{\prime} \mathrm{N}, 11^{\circ} 00^{\prime} \mathrm{E}$ & 985 & $\begin{array}{l}\text { Apr 1998-Aug } 2000 \\
\text { Apr 2008-Apr } 2009\end{array}$ & $\begin{array}{l}\text { Birmili et al. (2003) } \\
\text { Manninen et al. (2010) }\end{array}$ \\
\hline Värriö, Finland & $67^{\circ} 46^{\prime} \mathrm{N}, 29^{\circ} 35^{\prime} \mathrm{E}$ & 400 & 2003-2004 & Dal Maso et al. (2007) \\
\hline Pallas, Finland & $67^{\circ} 58^{\prime} \mathrm{N}, 24^{\circ} 07^{\prime} \mathrm{E}$ & 560 & $\begin{array}{l}\text { 2003-2004 } \\
\text { Apr 2008-Apr } 2009\end{array}$ & $\begin{array}{l}\text { Dal Maso et al. (2007) } \\
\text { Manninen et al. (2010) }\end{array}$ \\
\hline Vavihill, Sweden & $56^{\circ} 01^{\prime} \mathrm{N}, 13^{\circ} 09^{\prime} \mathrm{E}$ & 172 & $\begin{array}{l}\text { Feb 2001-May } 2004 \\
\text { Apr 2008-Feb } 2009\end{array}$ & $\begin{array}{l}\text { Kristensson et al. (2011) } \\
\text { Manninen et al. (2010) }\end{array}$ \\
\hline Finokalia, Greece & $35^{\circ} 20^{\prime} \mathrm{N}, 25^{\circ} 40^{\prime} \mathrm{E}$ & 250 & $\begin{array}{l}\text { Apr 2008-Apr } 2009 \\
\text { Apr 2008-Apr } 2009\end{array}$ & $\begin{array}{l}\text { Pikridas et al. (2012) } \\
\text { Manninen et al. (2010) }\end{array}$ \\
\hline Cabauw, Netherlands & $51^{\circ} 57^{\prime} \mathrm{N}, 04^{\circ} 53^{\prime} \mathrm{E}$ & 0 & Apr 2008-Mar 2009 & Manninen et al. (2010) \\
\hline K-Puszta, Hungary & $46^{\circ} 58^{\prime} \mathrm{N}, 19^{\circ} 35^{\prime} \mathrm{E}$ & 125 & Mar 2008-Feb 2009 & Manninen et al. (2010) \\
\hline Puy de Dôme, France & $45^{\circ} 42^{\prime} \mathrm{N}, 03^{\circ} 13^{\prime} \mathrm{E}$ & 1465 & $\begin{array}{l}\text { Feb 2007-Jun } 2010 \\
\text { Apr 2008-Apr } 2009\end{array}$ & $\begin{array}{l}\text { Boulon et al. (2011) } \\
\text { Manninen et al. (2010) }\end{array}$ \\
\hline Jungfraujoch, Switzerland & $46^{\circ} 32^{\prime} \mathrm{N}, 07^{\circ} 57^{\prime} \mathrm{E}$ & 3580 & $\begin{array}{l}\text { Apr 2008-Apr } 2009 \\
\text { Apr 2008-Apr } 2009\end{array}$ & $\begin{array}{l}\text { Boulon et al. (2010) } \\
\text { Manninen et al. (2010) }\end{array}$ \\
\hline
\end{tabular}

model results for all 13 stations. The measurement sites, the measurement periods and references to the data are given in Table 1.

\subsection{Event classification}

The classification of modelled nucleation events is based on two criteria. First, the $J_{3 \mathrm{~nm}}$ values have to be over $0.01\left[\mathrm{~cm}^{-3} \mathrm{~s}^{-1}\right]$ for two sequential hours. This limit comes from the lower detection limit of the instruments used in Hyytiälä and San Pietro Capofiume. Second, for the same time period, the rate of number concentration change with respect to change in logarithmic diameter for $3 \mathrm{~nm}$ particles has to be over $2000 \mathrm{~d} N / \mathrm{d}_{\log } D_{p}\left[\mathrm{~cm}^{-3}\right]$. This value is derived directly from the aerosol size distributions by comparing them and the $J_{3 \mathrm{~nm}}$ values. According to our tests, this approach classifies the event days realistically, but some error is introduced in specific cases; for example, when a nucleation event is terminated prematurely due to rain, etc. Nevertheless, these cases are not very common in the model and the criteria work very well for the modelled data.
The event classification used for measurements (Hyytiälä, Melpitz and San Pietro Capofiume) was conducted by Jaatinen et al. (2009) with the method based on Dal Maso et al. (2005). A day is considered an event day when the formation of new aerosol particles starts at the lowest measurable particle size (diameter $3 \mathrm{~nm}$ ) and subsequent growth of the newly formed particles is observed for several hours. The nucleation event classification is based on event clarity - i.e. the number concentrations of the freshly formed particles, and their formation and growth rates. For more details on the classification method, see Hamed et al. (2007).

\section{Comparison with measurements}

\section{$3.1 \quad J_{3} \mathrm{~nm}$ values}

The measured and modelled $J_{3 \mathrm{~nm}}$ values are compared in Fig. 2. Since the measurement data are only for the nucleation event days, the same approach is made to model data using the event classification method described in Sect. 2.6. 

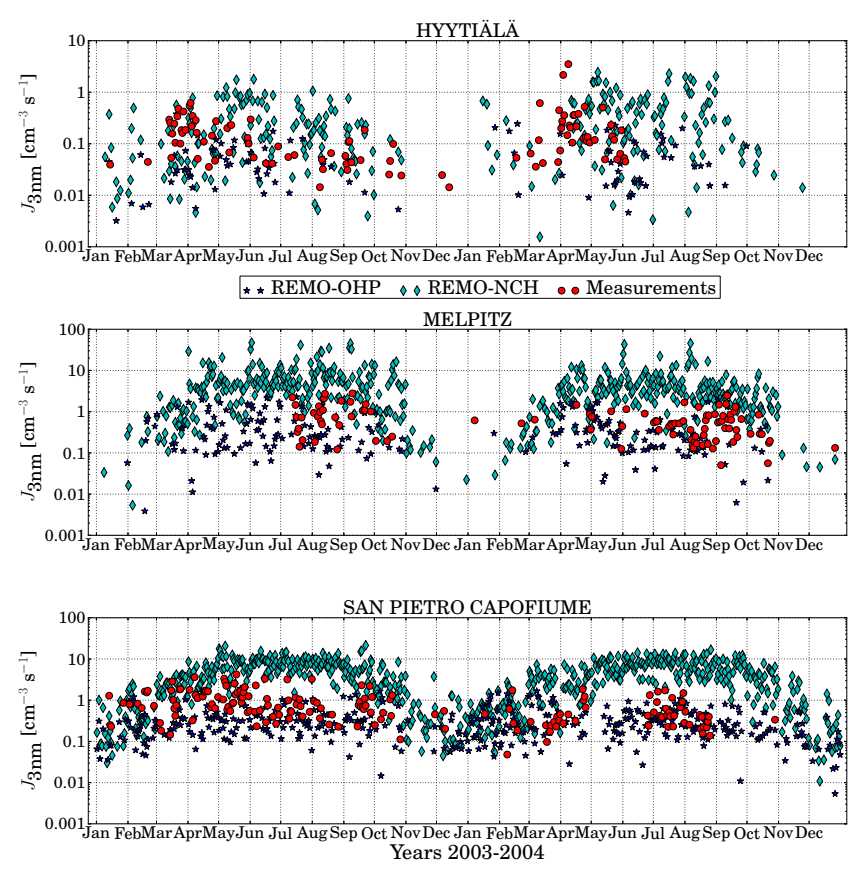

Figure 2. Measured and modelled daily mean $J_{3 \mathrm{~nm}}$ rates for event days at Hyytiälä, Melpitz and San Pietro Capofiume.

Overall, the measurements show that Hyytiälä and Melpitz have the highest nucleation rates in the spring and autumn, whereas in San Pietro Capofiume the values are quite high during all seasons except winter. Both of the model versions show similar features, although REMO-OHP cannot reproduce the high rates in Hyytiälä during the autumn. REMO$\mathrm{NCH}$ shows overall much higher values at all locations and the values have a maximum during the summer.

The mean $J_{3 \mathrm{~nm}}$ values show that REMO-OHP is able to reproduce measured NPF rates at Hyytiälä, although overall some underestimation can be seen; the relative difference of 2-year mean $\Delta_{\mathrm{r}}$, calculated by first subtracting the measured mean from the model mean, then dividing this by the measured mean and finally multiplying this by $100 \%$, is $\Delta_{\mathrm{r}}=-71 \%$. The highest measured rates are not captured during the spring by REMO-OHP, whereas the summer values are in good agreement. For REMO-NCH, the values are also quite realistic, but overestimated $\left(\Delta_{\mathrm{r}}=66 \%\right)$. During summer, the REMO-NCH values are over 10 times too high, but in the spring, REMO-NCH reproduces the measured rates more realistically than REMO-OHP, which underestimates the values by a factor of 5-10. This shows that, seasonally, the new model version still has deficiencies.

Similar behaviour as in Hyytiälä can also be seen at Melpitz and San Pietro Capofiume. At these locations, the overestimation of REMO-NCH is larger, especially at San Pietro Capofiume. The $\Delta_{\mathrm{r}}$-values for REMO-OHP are $-35 \%$ and $-60 \%$ at Melpitz and San Pietro Capofiume, respectively. For REMO-NCH, the corresponding values are $590 \%$ and
$393 \%$. REMO-OHP underestimates the rates during the autumn peaks in Melpitz, whereas in San Pietro Capofiume the autumn rates are in good agreement. During the summer, REMO-OHP underestimates the values in Melpitz and San Pietro Capofiume, especially in the latter. Although not perfect, REMO-OHP produces quite realistic $J_{3 \mathrm{~nm}}$ values and performs clearly better in this respect than REMO-NCH. The underestimation in REMO-OHP may come from the chemistry part, but also from the nucleation parametrization. For example, better representation of organics and their influence to the nucleation rates could lead to more realistic $J_{3 \mathrm{~nm}}$ values (in both model versions). Currently, the influence of organics comes indirectly from the kinetic coefficient $K$ in Eq. (3), which is based on measurement and includes the effect of organics (if any). We chose this approach as the model does not have an SOA module. Besides the nucleation rates, the length of the events is also an important factor for the total number of nucleated particles. This is analysed in the next section.

\subsection{Start and end time/duration of events}

The measurement data for Hyytiälä, Melpitz and San Pietro Capofiume also includes the nucleation event start time, end time and (calculated) length. For these variables, monthly statistics for the measurements and modelled results are derived.

Figure 3 shows that, at Hyytiälä, REMO-OHP can reproduce the event length realistically for most of the modelled period, excluding some overestimation periods during summer/autumn of 2004. In REMO-NCH, the overestimation of event length can be seen throughout the year, excluding spring, where the model reproduces measured values fairly well. For the event start times, REMO-OHP results are in good agreement with the measurements, although it has delayed start times during the spring and summer of 2003. On the other hand, the REMO-NCH events start $1-3 \mathrm{~h}$ too early and the difference is biggest during the summer months, especially during 2004 . The end times of the events show more fluctuations, but overall the agreement between the measurements and REMO-OHP is good. However, during the summer/autumn of 2004, REMO-OHP shows a strong delay in event end times (up to $5 \mathrm{~h}$ ). Similar behaviour can be seen with REMO-NCH, which tends to delay the event ends for almost the whole modelled period.

At Melpitz, REMO-OHP overestimates the event lengths. Seasonally, the model shows $4 \mathrm{~h}$ overestimations in the spring, $0-4 \mathrm{~h}$ during the summer and $2-4 \mathrm{~h}$ in the autumn. REMO-NCH has similar trend, but the overestimations are worse; $8-10 \mathrm{~h}$ in the spring, $6-8 \mathrm{~h}$ in the summer and $6 \mathrm{~h}$ in the autumn. REMO-OHP captures event start times very well for 2003, but during 2004, the model gives too early start times for the first half of the year. For the second half, the start times are delayed, but the difference stays within a couple of hours. In REMO-NCH, the events start a few hours too 

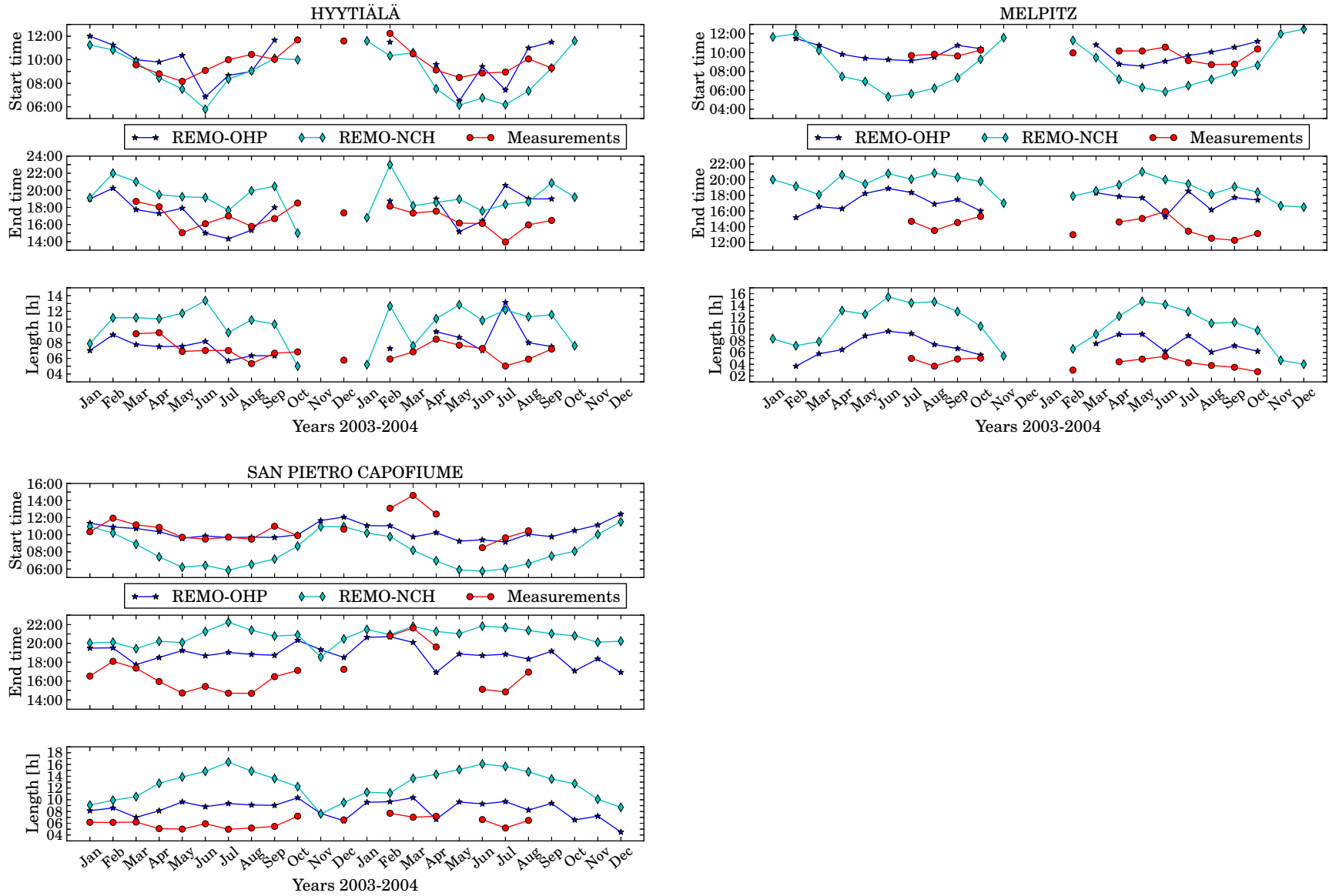

Figure 3. Monthly mean event start time, end time and length at Hyytiälä, Melpitz and San Pietro Capofiume. Months without data or events have been dismissed.

early and the difference is highest during the summer and almost disappears during the late autumn and early spring (no data for winter, unfortunately). The end time of the events at Melpitz is not very well captured by either of the models; both show much later end times than the measurements. In particular, REMO-NCH has a tendency to delay the ending of the nucleation events substantially.

The aerosol distributions were also compared with the measurements analysed by Hamed et al. (2010) (not shown). This comparison showed that the model results underestimate the number concentration of particles $>100 \mathrm{~nm}$ by a factor of 2 (similar behaviour can be also seen for the aerosol distributions in an earlier study by Pietikäinen et al., 2012). One possible reason for this is the missing growth caused by condensable organics, which would lead to higher concentrations of particles $>100 \mathrm{~nm}$. Either way, the lower particle number concentration leads to smaller surface area and condensation sink. This might be the key factor in understanding why the model overestimates the event lengths at Melpitz: if the condensation of $\mathrm{H}_{2} \mathrm{SO}_{4}$ is too slow during the nucleation event, $\mathrm{H}_{2} \mathrm{SO}_{4}$ will continue to cause nucleation for a longer period until it has been removed. On the other hand, higher pre-existing condensation sink (which would be expected if SOA was included in the model) would lead to lower $\mathrm{H}_{2} \mathrm{SO}_{4}$ concentrations and decrease the $J_{3 \mathrm{~nm}}$ values. This effect, however, would not be very strong, because the nucleation events usually start when the air is clean (measurements show low condensation sink) and during this time $\mathrm{H}_{2} \mathrm{SO}_{4}$ concentrations would stay almost as high as without SOA in the model. This eventually leads back to the point that nucleation events would be shorter with SOA in the model due to increased condensation sink and faster depletion of $\mathrm{H}_{2} \mathrm{SO}_{4}$, as the events progress.

The results from San Pietro Capofiume show that REMOOHP overestimates the event lengths by $2 \mathrm{~h}$, throughout the year, whereas REMO-NCH overestimates them by $2-10 \mathrm{~h}$ (maximum being in the summer). The event start times in REMO-OHP are almost identical with measurements in 2003 , but during the beginning of 2004, the model has a tendency to initiate nucleation slightly too early. This bias, however, decreases during the summer. REMO-NCH has a systematical bias to start the events too early and seasonally, the difference is smallest during the winter and highest during the summer. The same mechanism applies here as for 

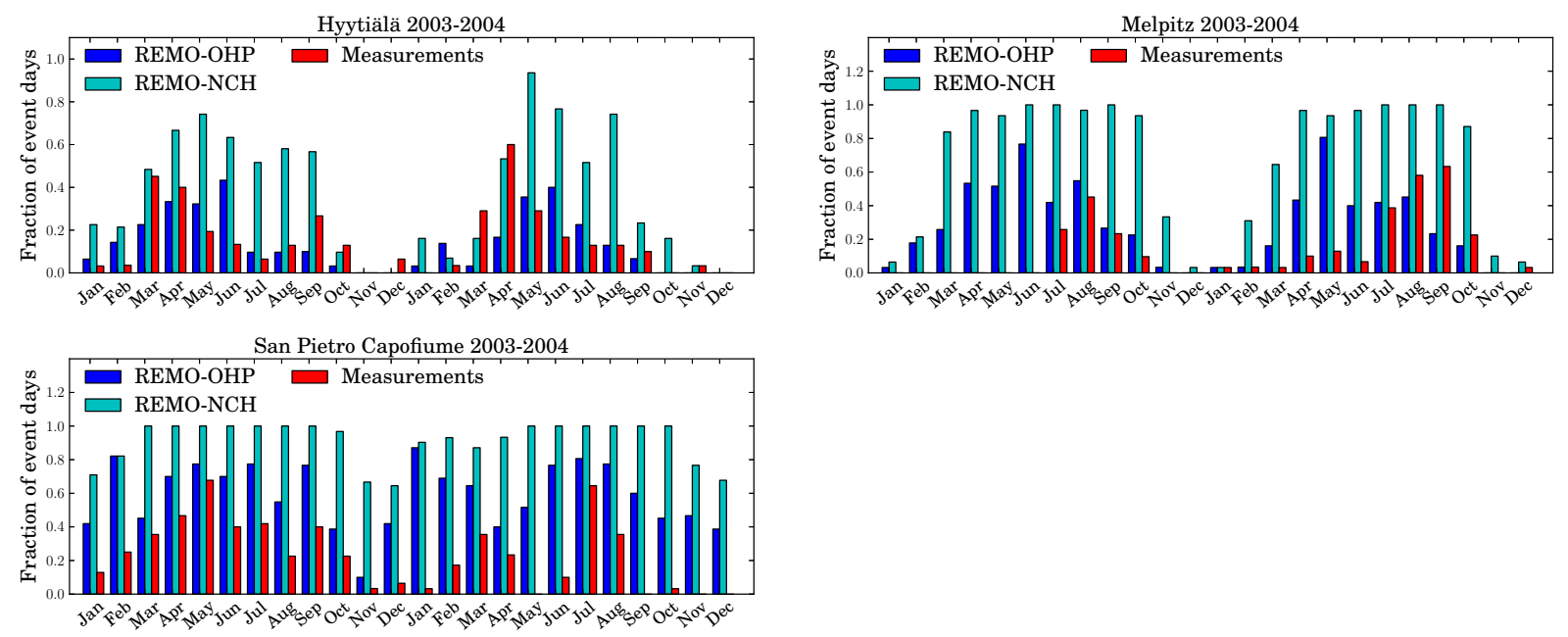

Figure 4. The fraction of days with NPF events, 2003-2004, at 3 European observation sites on a monthly basis. The graph compares model simulations with observational evidence.

Melpitz: the low condensation sink of $\mathrm{H}_{2} \mathrm{SO}_{4}$ in the models is the most probable reason for the delays in the nucleation end times.

The simplified sulfate chemistry module could also be one reason for the continuation of the Melpitz and San Pietro Capofiume events. The OH-proxy is based on measurements from Hyytiälä, which means that the influences of other relevant chemical species to $\mathrm{OH}$ concentrations are based on Hyytiälä conditions. For example, nitrogen oxides (NOx) and volatile organic compounds (VOCs) are species competing for the reaction with OH (Seinfeld and Pandis, 1998). The $\mathrm{VOC} / \mathrm{NO}_{\mathrm{x}}$ ratio dictates which species is predominant in the reaction. As the information about the average $\mathrm{VOC} / \mathrm{NO}_{\mathrm{x}}$ ratio is now implicitly included in the proxy through measurements from Hyytiälä, error may be caused in environments where the typical $\mathrm{VOC} / \mathrm{NO}_{\mathrm{x}}$ ratios differ from those in Hyytiälä. This will impact the $\mathrm{H}_{2} \mathrm{SO}_{4}$ concentrations and could partially explain why the $J_{3 \mathrm{~nm}}$ values have different biases and why the length of events is not captured similarly in different locations.

\subsection{Fraction of event days}

The fraction of event days per month is analysed from all measurement stations. This section is divided into two parts, which are based on the simulation periods.

\subsubsection{Years 2003 and 2004}

The measured and modelled monthly fractions of nucleation days for Hyytiälä, Melpitz and San Pietro Capofiume are shown in Fig. 4. The measurement data have some gaps, because measurements were not available for the entire twoyear period (details in Table 1).
REMO-OHP underestimates the fraction of nucleation days per month in spring and overestimates it in early summer at Hyytiälä. For autumn, the model underestimates the fraction in 2003 (reproducing only half of the nucleation days), but captures the events in 2004. REMO-NCH overestimates the fraction almost throughout the modelling period, going up to five times higher event frequency. Late autumn in 2003 and spring 2004 are the only times when REMO$\mathrm{NCH}$ underestimates or comes even close to the measurements. Overall, the values from the model simulations are not a perfect match, but REMO-OHP shows much better agreement.

For Melpitz, Fig. 4 shows that REMO-OHP slightly overestimates the nucleation events for the year $2003(0-15 \%)$. For 2004, REMO-OHP overestimates the values for the first half of the year (up to a factor of 5) and underestimates them for the second; for example, getting less than half of the events during September. With REMO-NCH, the fraction of monthly nucleation days is overestimated in every month. The low fraction in measurements for summer 2004 can be partly explained by the high number of undefined days (up to 14 days per month) (Jaatinen et al., 2009).

At San Pietro Capofiume, REMO-OHP tends to predict nucleation events too frequently by $30-50 \%$ for both years, especially during wintertime (Fig. 4). If January and February are disregarded, the pattern of the first year is well captured by REMO-OHP. REMO-NCH shows high overestimations, especially during summertime. For many months, REMO-NCH show nucleation fractions of 1.0. Even during the winter, more than $60 \%$ of the days show nucleation events. Pietikäinen et al. (2012) showed that the model has a positive $\mathrm{SO}_{2}$ bias, which can lead to elevated $\mathrm{H}_{2} \mathrm{SO}_{4}$ values. The bias is relatively high in polluted areas, and location such as San Pietro Capofiume falls into this category (Laaksonen et al., 2005, and references therein). Despite the 
improved $\mathrm{OH}$ chemistry presented in this work, the results for San Pietro Capofiume are affected by the positive $\mathrm{SO}_{2}$ bias.

In addition to the measurement-based analysis conducted for Hyytiälä, Melpitz and San Pietro Capofiume, an analysis based on observation data from literature was performed. Figure 5 shows the fraction of nucleation days per month for these locations (more details in Table 1). For Mace Head, data from Yoon et al. (2006) are used. Two types of nucleation events are observed in Mace Head: the coastal events, driven by iodine species emitted by algae during low tides, and the continental type of events; i.e. sulfuric acid-driven events similar to those observed at the other stations. The former type of nucleation is not included in REMO-HAM, making the comparison between simulations and observations somewhat complicated. However, Yoon et al. (2006) provided two kinds of nucleation event statistics: the total number of events, and the number of events for cases in which clean marine air masses advected over tidal areas to the measurement station. While some of the latter events may be of the continental type, it is clear that most of them are coastal (see also O'Dowd et al., 2002). Similarly, it is likely that the majority of the rest of the events (polluted cases, i.e. total events minus clean events) are of the continental type.

Figure 5 shows the total number of nucleation events and the difference between the total and clean air mass cases (shown as $\Delta$ Yoon et al., 2006). The model results for Mace Head show that, if compared to all event cases, REMO-OHP underestimates the nucleation days for the whole simulation period. On the other hand, REMO-NCH gives reasonably realistic results. In addition, the overestimation seen before in REMO-NCH is not present. However, if the $\triangle$ Yoon et al. (2006) results are compared, results from REMO-OHP show better agreement. The model still underestimates the event numbers during both winter and spring 2003, but the absolute difference is much smaller. During spring 2004, and both summers and autumns, REMO-OHP is able to capture the measured statistics that have even slight overestimations in some cases. REMO-NCH overestimates the values for all months.

At Hohenpeißenberg, REMO-OHP reproduces the measured values with good accuracy. Also, the yearly cycle is in reasonable agreement with measurements. There are some months, for example during spring, when the model overestimates the number of event days. On the other hand, underestimation occurs in autumn and winter, but the absolute difference is quite small. REMO-NCH shows realistic results only during the winter time. During other periods, the model overestimates the event day fraction 3-5 times.

The results from Värriö show that REMO-OHP underestimates the measured nucleation event frequencies by roughly a factor of two. The biggest difference is that the model fails to reproduce the observed autumnal nucleation events. This is more realistically captured with REMO-NCH, which overestimates the values for the first half of the year, but is in good agreement with measurements otherwise. Similarly, the missing autumn nucleation in REMO-OHP can be seen at Pallas. There, REMO-OHP does not underestimate the values as much as at Värriö. Besides autumn, only the spring of 2003 is underestimated; otherwise, values are close to measurements. REMO-NCH has similar behaviour at Pallas as at Värriö, although the overestimation is slightly more frequent.

Autumn nucleation events also seem to be a problem for REMO-OHP at Vavihill. In addition, the winter nucleation is underestimated or missing, but otherwise the model is able to reproduce the event fractions realistically. REMO-NCH is able to get the late-winter events, but overestimates the summer values. Moreover, the autumn is better captured with REMO-NCH than REMO-OHP.

It is not clear why the autumn nucleation is missing from the simulated climate. In order to rule out problems in the nucleation classification method, the banana plots showing the evolution of aerosol size distribution during the day were studied (details not shown here). The banana plots did not show any clear nucleation events during autumn, which means that the classification does work. There are few candidates to explain why the autumn time nucleation is not captured by the model. It is possible that the sulfuric acid concentrations are too low. This is supported by the earlier study on black carbon concentration over Finland by Hienola et al. (2013), who reported deficiencies in the used emission database. Although the analysis in their study was done for black carbon, the database could also have similar problems for other species, such as $\mathrm{SO}_{2}$. Higher-resolution data (spatial and temporal) could help to improve the sulfuric acid concentrations, especially at remote places like Värriö and Pallas, where small concentration changes could have a big impact on nucleation. On the other hand, the kinetic nucleation scheme employed in the model may well be too simple. Taking into account condensable organics could improve the results (Andreae, 2013). Also, the kinetic coefficient used should ideally not be treated as a constant, as the nucleation rates probably vary with meteorological parameters and some chemical species. However, the current level of understanding of the nucleation process does not permit accounting for these factors.

\subsubsection{Years 2008 and 2009}

For 2008 and 2009 the simulations are conducted only with REMO-OHP. As the previous sections have shown, REMO$\mathrm{NCH}$ produces too-high nucleation rates and event frequencies. For this reason, in Fig. 6, only the REMO-OHP model run is shown.

At Hyytiälä, REMO-OHP shows that the predicted nucleation events in springtime are underestimated, during summer some overestimation can be seen and in autumn the nucleation seems to be missing. Nevertheless, the yearly cycle is captured (autumn excluded) and the values are reasonably close to the measurements. In Melpitz, the model 

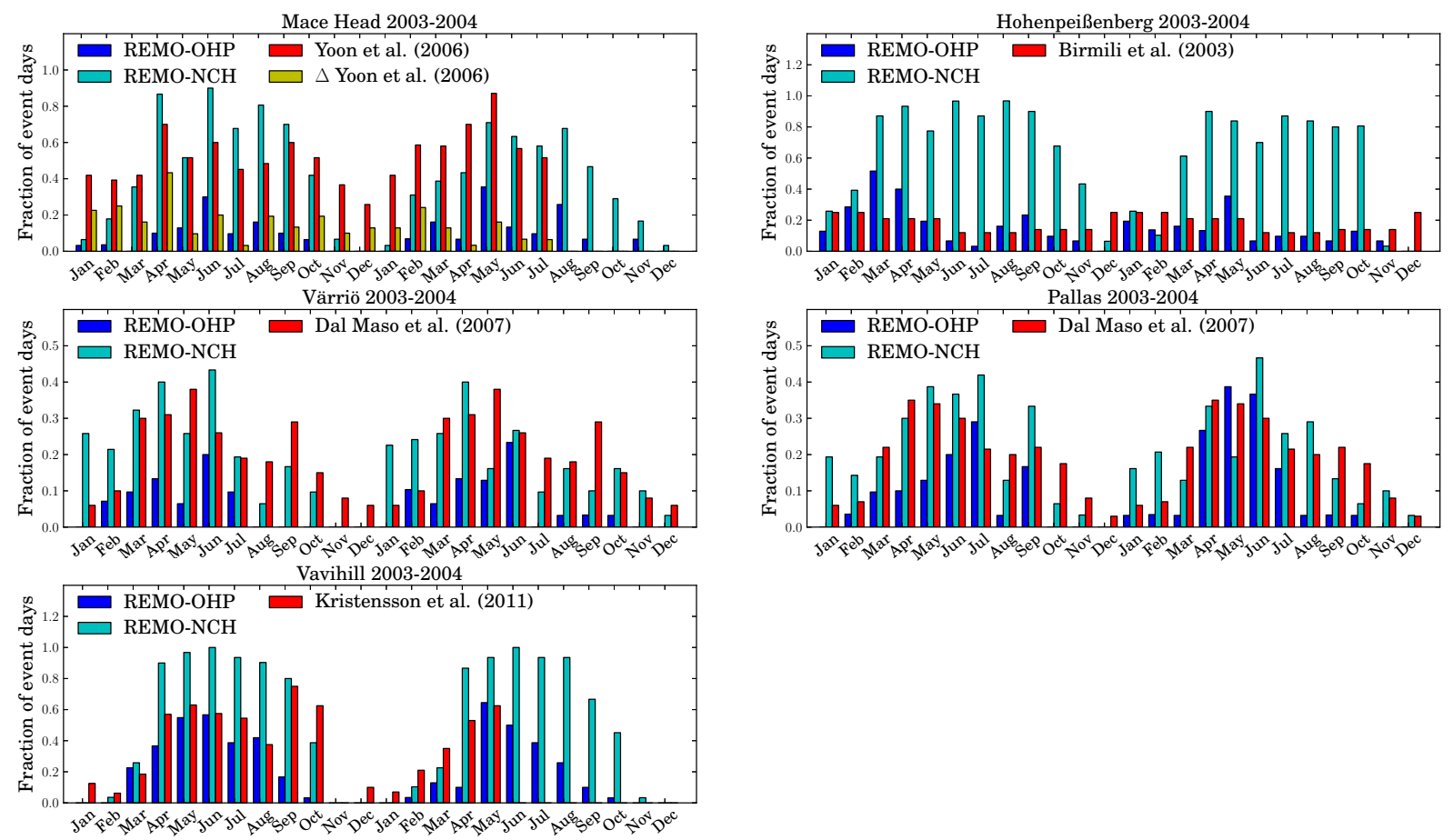

Figure 5. The fraction of days with NPF events, 2003-2004, at five European observation sites on a monthly basis.

underestimates the fraction of events, while the analysis for 2003 and 2004 showed overestimations (Fig. 4). The underestimation is fairly strong for both years. The yearly cycle is captured, although the winter events are missing. The emission database used is for the year 2000 (Dentener et al., 2006), and it is surprising that the model is underestimating the 2008 and 2009 result, because the $\mathrm{SO}_{2}$ emissions are known to have decreased over the last 2-3 decades (Hamed et al., 2010, and references therein). On the other hand, this could imply the same possible cause described in the previous section: the nucleation scheme used needs to have more input parameters in terms of other compounds.

For San Pietro Capofiume, data coverage from the literature is quite limited. Still, the same features as for 2003 and 2004 can be seen: the model overestimates the number of nucleation events. At Mace Head, the results show similar underestimation as in 2003 and 2004. The results from REMOOHP at Hohenpeißenberg for 2003 and 2004 were very close to measurements. For 2008 and 2009, the model does not capture all the events. Again, taking into account the emission reductions for sulfuric species, this result is surprising. It appears that, although sulfuric acid can be considered the main driver for nucleation, the simplistic approach using it as the only participating species should be improved. The same applies to Pallas, where similar underestimation can be seen. At Vavihill, the model can reproduce the measured values better, although it has a slightly underestimating bias.

The Finokalia results show large overestimations in spring, summer and autumn. In winter, the model tends to underes- timate the results when compared to both literature sources. The reason for the overestimation could stem from too-high solar radiation levels in the model. The model cloudiness was, therefore, compared against ERA-Interim data, but no clear bias was found. Another possible reason could be the DMS and $\mathrm{OH}$ concentrations. As mentioned in Sect. 2.2, DMS is oxidized by $\mathrm{OH}$ during the day time. The location of Finokalia provides enough sunlight for $\mathrm{OH}$; so, if these two are overestimated, the nucleation will show patterns similar to Fig. 6. The influence of other sulfuric acid sources cannot be excluded; but, taking the Finokalia location into account, the combination of overestimated DMS and $\mathrm{OH}$ appears to be the most credible explanation. Also, the proxy is quite simple and the results from Finokalia show that more input parameters should be employed in order to get a better representation of the regional characteristics.

At Cabauw, the model predicts a yearly nucleation maximum during the spring, whereas, in measurements, it is in the summer. The modelled values are slightly lower than the measured, and the autumn peaks are missing. At K-Puszta, the values are closer to the measurements. For summer, the nucleation event frequency is even overestimated. The measurements show that the yearly maximum should be during springtime, whereas in the model, the peak occurs in summertime. The measurements show that it should be during the springtime. Overall, the values are quite realistic and of the same magnitude as the measurements. 


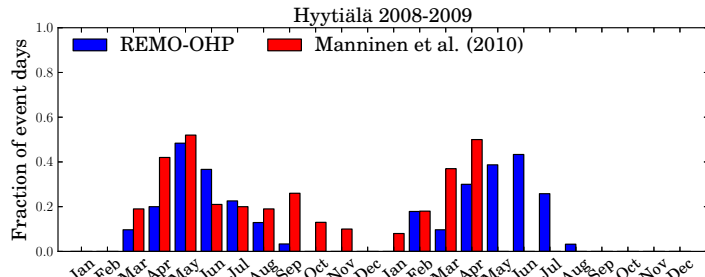

San Pietro Capofiume 2008-2009
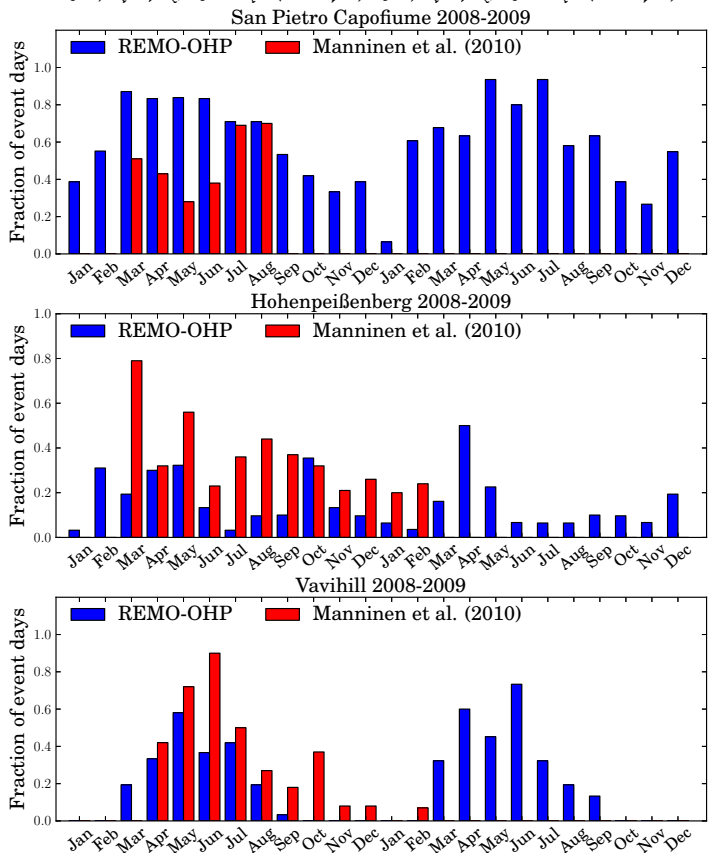

Cabauw 2008-2009
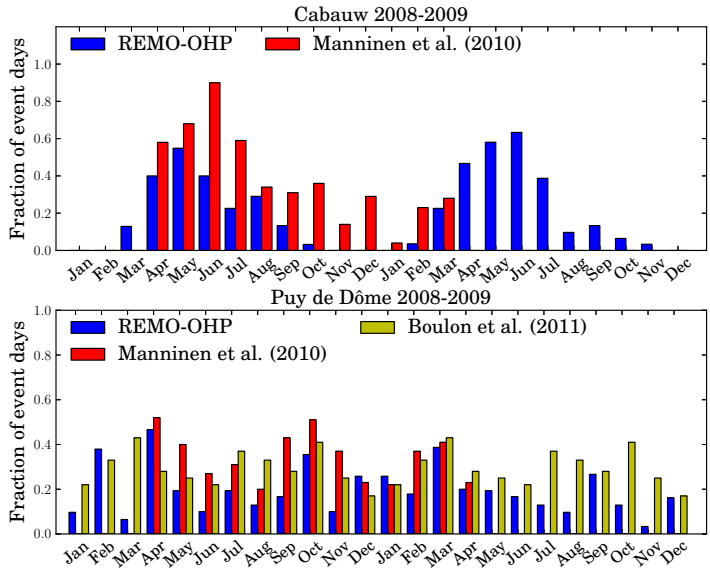
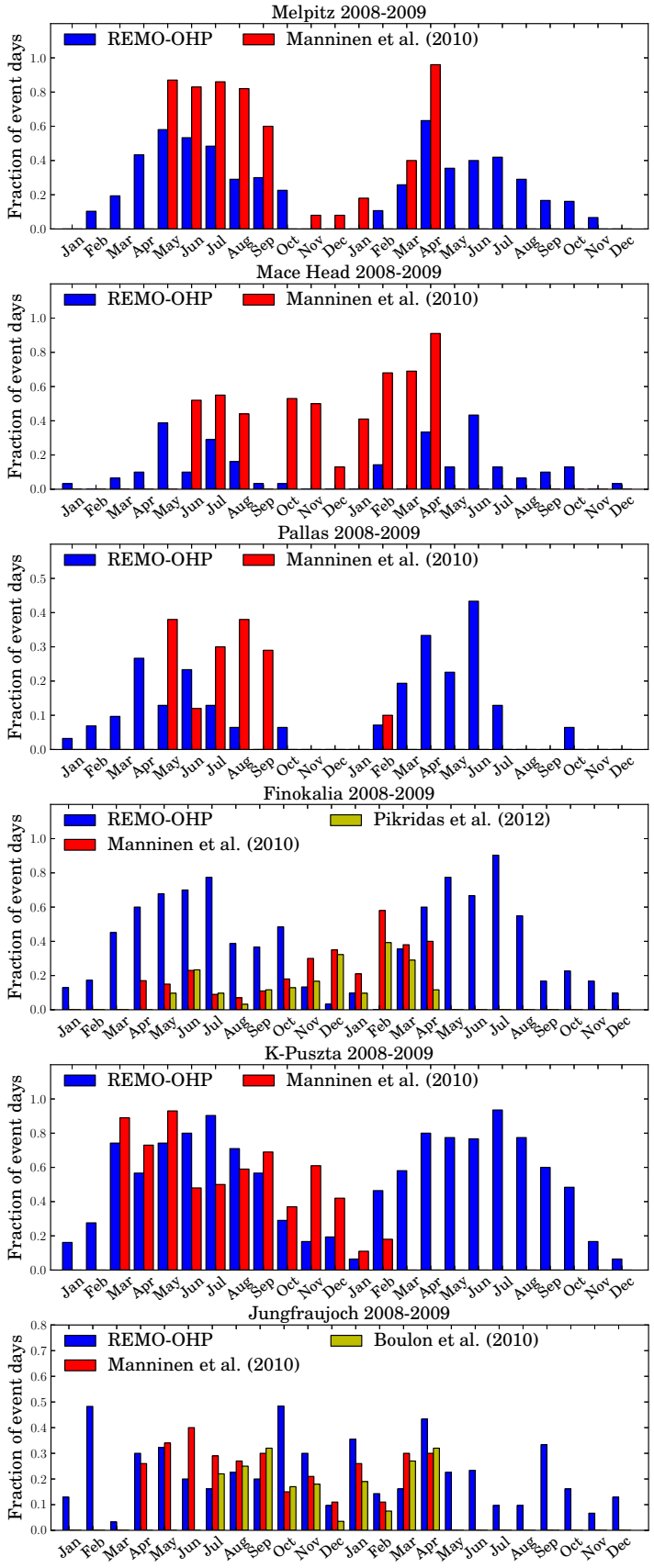

Figure 6. The fraction of days with NPF events, 2008-2009, at 12 European observation sites on a monthly resolution.

Puy de Dôme is a location where the model gives very realistic results. The overall tendency is slightly underestimated, but the yearly cycle is well captured. This also holds true for Jungfraujoch, although there the model produces some overestimation. Overall, these results are very good considering the mountainous location, which are known to be difficult for the model dynamics (Pietikäinen et al., 2012).

\subsection{Vertical extent of nucleation}

Figure 7 shows example periods of modelled nucleation at Hyytiälä, Melpitz and San Pietro Capofiume. The nucleation events are strong at Hyytiälä, but the growth seems to be missing. There are at least two possible explanations for this: the model lacks condensable organics, and the representation of the aerosol population with seven log-normal modes leads to problems, as is shown by Korhola et al. (2013). In the latter case, the particles grow due to the condensation 

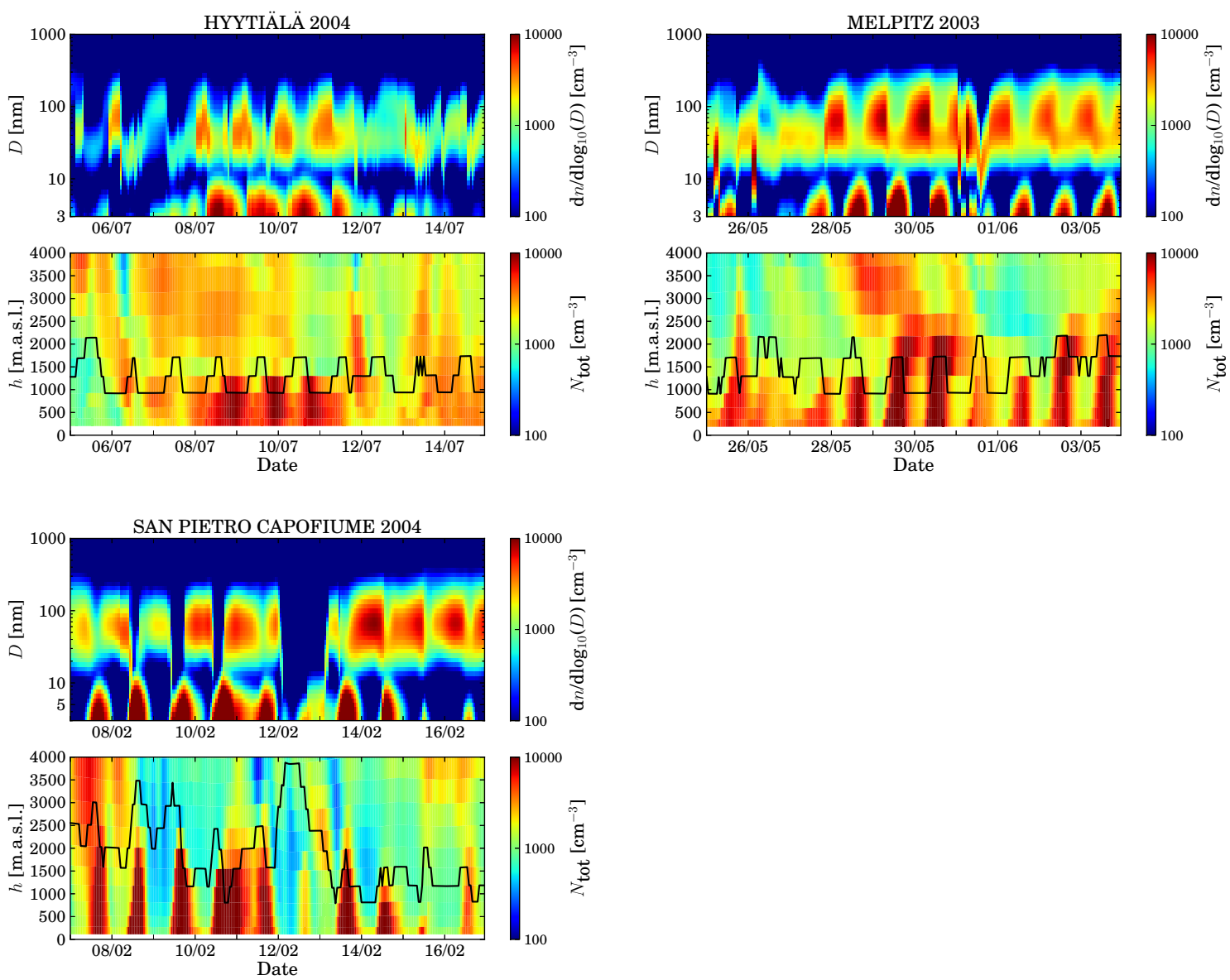

Figure 7. Nucleation events and total number concentration from Hyytiälä (5 to 15 July 2004), Melpitz (25 May to 4 June 2003 ) and San Pietro Capofiume ( 7 to 17 February 2004). The black line shows the height of the boundary layer.

of sulfuric acid and coagulation, but the mode structure is unable to show this as a continuous phenomenon. Instead, Fig. 7 shows how the particles have "moved" directly to Aitken/accumulation mode sizes.

The vertical evolution of events reveals that, at Hyytiälä, nucleation takes place mostly inside the boundary layer. In some cases, the concentrations above the boundary layer are also very high. This is a known phenomena in ECHAM5HAM (Kazil et al., 2010) and has also been shown to exist REMO-HAM (Pietikäinen et al., 2012). In addition, the $\mathrm{OH}$ proxy is a function of radiation and is based on surface measurements. This might cause some error at higher altitudes.

At Melpitz, the nucleation bursts are much stronger than at Hyytiälä (Fig. 7). It is noticeable that, during the night time, the accumulation mode number concentration increases. This happens when the particles in Aitken mode coagulate with the accumulation mode particles. As mentioned before, the model does not have an online SOA module, which means that the only condensable species is sulfuric acid. During the night, the $\mathrm{H}_{2} \mathrm{SO}_{4}$ concentrations are low, so only coagulation is active. As the accumulation and coarse modes do not co- agulate in M7, the number concentration starts to increase. Like at Hyytiälä (although shown much more clearly), the Aitken/accumulation mode is flushed away during the morning. This can be also seen from measurements (not shown here). The reason for this is the boundary layer mixing during the morning, which is caused by solar heating. At the same time, nucleation bursts can be seen. Vertically the situation is similar to that at Hyytiälä: in some cases, nucleation bursts exceed the boundary layer. There are also some high number concentrations well above the boundary layer height. This can be explained by convective clouds: the vertical transport moves $\mathrm{SO}_{2}$ and $\mathrm{H}_{2} \mathrm{SO}_{4}$ to the mid and upper troposphere. There, the gases have the potential to trigger nucleation and, eventually, the particles will come down (Kazil et al., 2006). In the model, all the gas-phase sulfate is assumed to condense to cloud droplets in stratiform clouds, but this is missing for convective clouds, because the grid box cloud fraction is not defined in this case. The wet deposition is calculated in and below convective clouds, but during the vertical transport no gas-phase sulfate is assumed to condense to cloud droplets. 


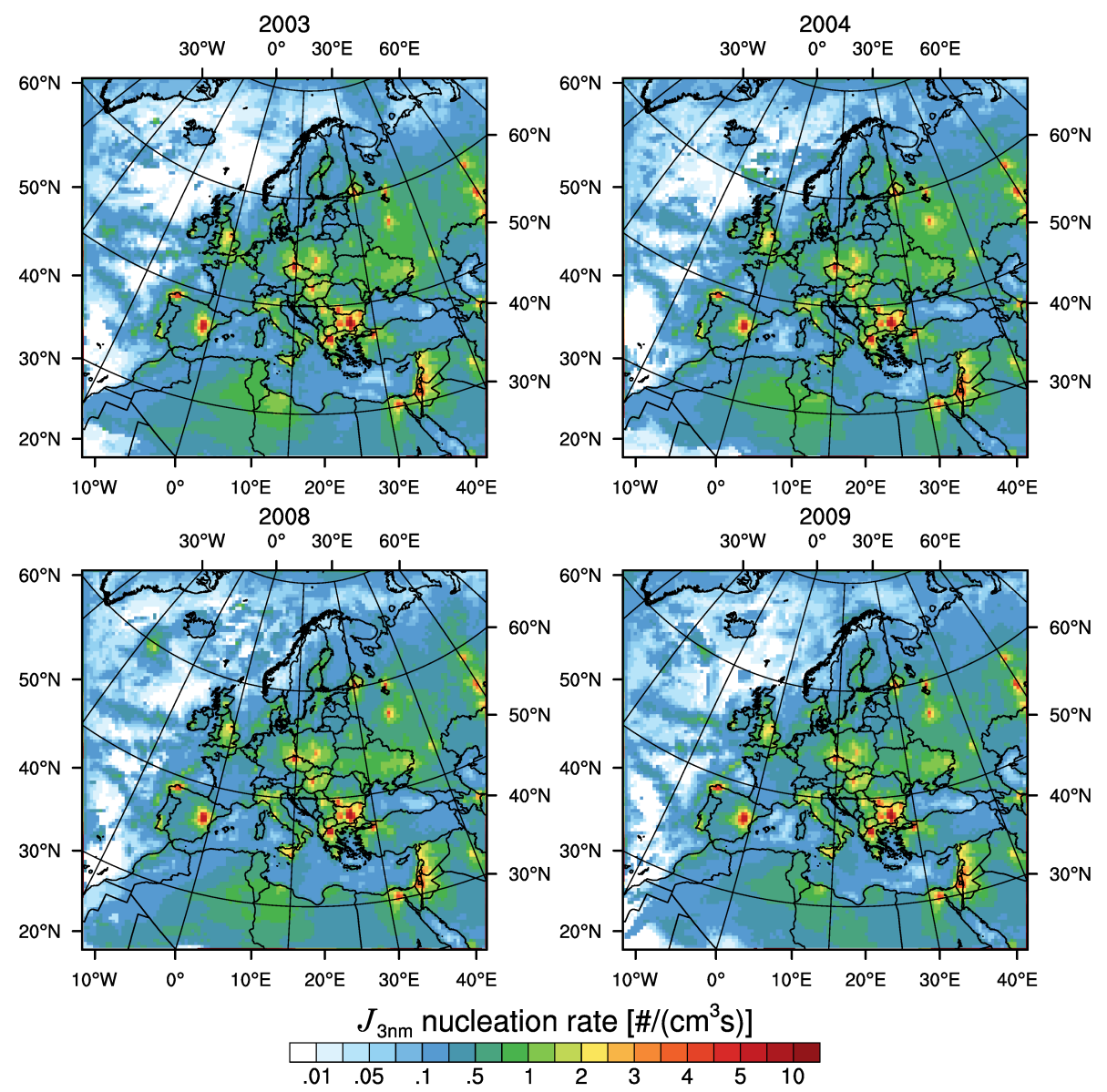

Figure 8. The yearly mean nucleation rates. Means are calculated only for data that met the event classification criteria presented in Sect. 3.3 .

This means that the convective clouds act in the model as an effective elevator for the aerosol species.

Laaksonen et al. (2005) reported that, at San Pietro Capofiume, the nucleated particles grow to $100 \mathrm{~nm}$ size in $10 \mathrm{~h}$ (on average, measurements from 24 March 2002 to $24 \mathrm{Au}$ gust 2004). This fits quite reasonably to our results (Fig. 7). Laaksonen et al. (2005) also showed that the largest particles reach sizes larger than $200 \mathrm{~nm}$ by midnight. The model also seems to be able to reproduce this behaviour. During 12-13 February 2004, the influence of precipitation can be seen: almost all of the particles are flushed from the boundary layer.

\subsection{Mean nucleation rates in Europe}

One interesting aspect of climate models is that the spatial extent of nucleation events can be studied. The approach used here is to apply the classification method explained in Sect. 3.3 for all grid boxes in every output step $(1 \mathrm{~h})$ and average only these cases.

Figure 8 shows the simulated average nucleation rates $J_{3 \mathrm{~nm}}$ (for periods when event classification criteria is met). On average, nucleation occurs in the model throughout Europe, with "hot spots" of strong nucleation near the peak emissions sources (industrial areas, cities, etc.). The ship tracks are also visible from the averaged nucleation values. More locally, for example, at Melpitz, the high nucleation rates seem to be linked to big industrial-point $\mathrm{SO}_{2}$ sources (power generation) in the easternmost parts of Germany and neighbouring countries (Czech Republic, Poland).

In order to calculate the strongest nucleation events in Europe, $J_{3 \mathrm{~nm}}$ is averaged for all output steps. Figure 9 shows the seasonal mean values for 2003 and 2004 (results are almost identical for 2008 and 2009 and are, thus, not shown). Nucleation is strongest during the spring and summer, as expected. Again, strong emission sources, as well as ship tracks, can be clearly seen from the maps. During autumn, nucleation rates are low in Fennoscandia, as was also seen in the nucleation event frequency statistics in Sect. 3.3. This may be due to model biases in meteorological conditions (especially cloud cover), emissions, and/or process parametrizations (kinetic nucleation, $\mathrm{OH}$-proxy).

\subsection{Spatial extent of events}

Nucleation events are naturally influenced by meteorological variables. This leads to very different nucleation events on 


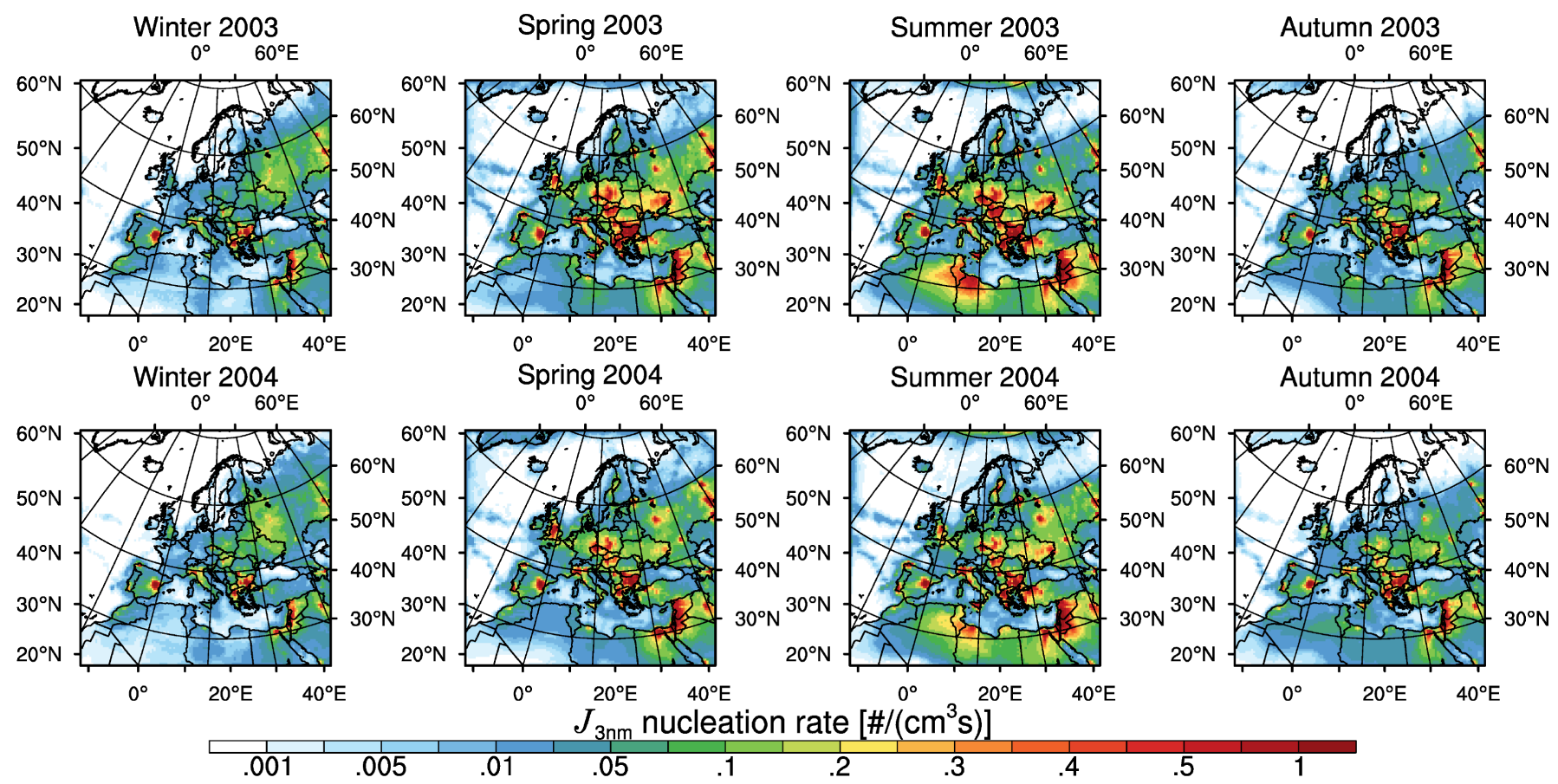

Figure 9. The seasonal mean nucleation rates for 2003 and 2004.
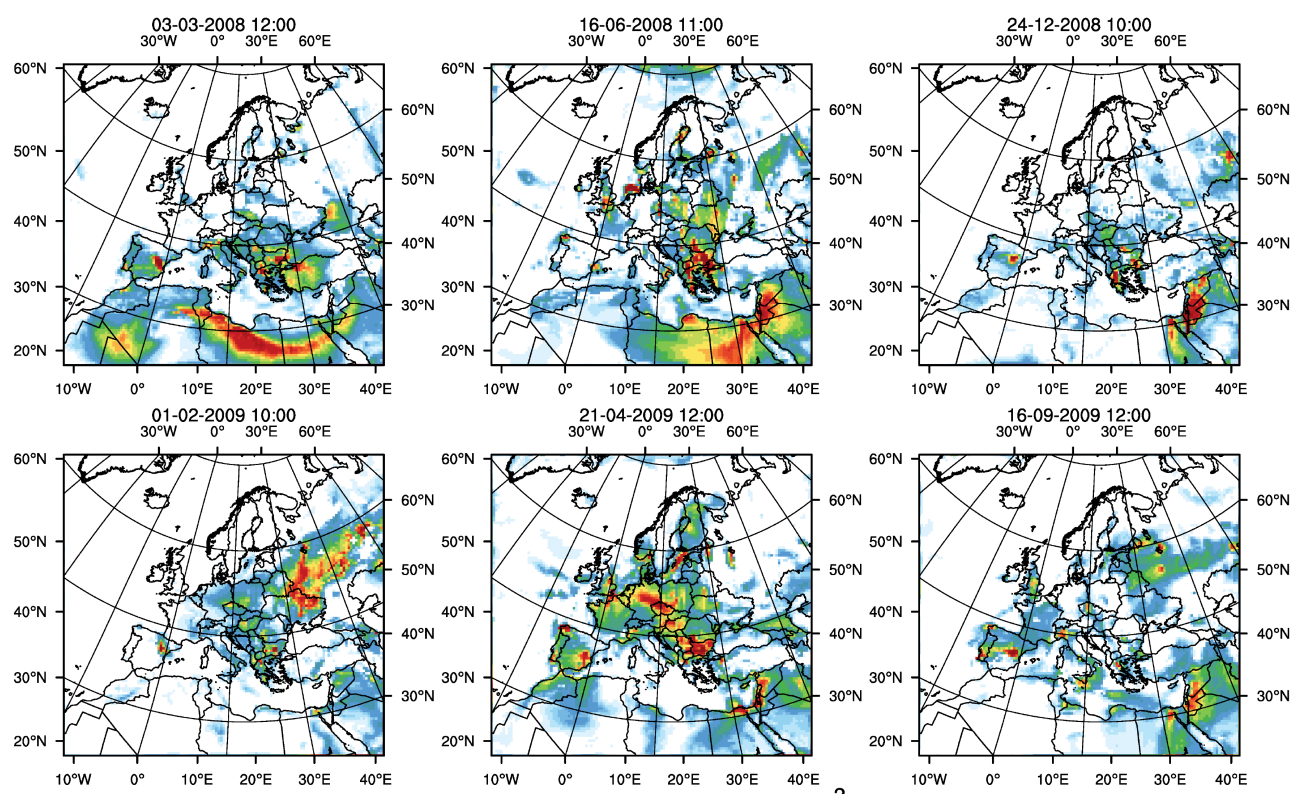

$J_{3 n m}$ nucleation rate [\#/( $\left.\left.\mathrm{cm}^{3} \mathrm{~s}\right)\right]$

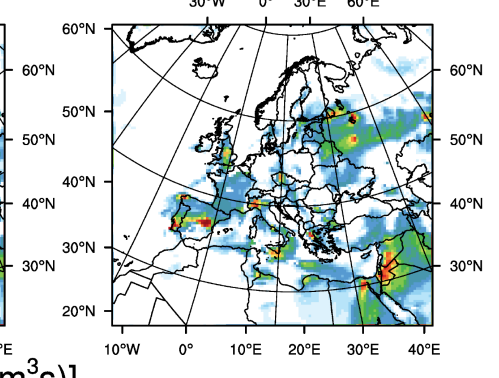

$\begin{array}{llllllllllllllll}.01 .03 .05 .08 & .1 & .25 & .5 & .75 & 1 & 1.5 & 2 & 2.5 & 3 & 3.5 & 4 & 4.5 & 5 & 7.5 & 10\end{array}$

Figure 10. Snapshot examples of 6 different European nucleation events.

a spatial scale. Figure 10 shows six nucleation event snapshots taken from the years 2008 and 2009. The top left panel (3 March 2008 12:00 UTC) shows how most parts of Europe are without substantial NPF, whereas northern Africa has quite strong events. The top centre panel (16 June 2008 11:00 UTC) shows nucleation happening mostly near the eastern part of Mediterranean Sea. The top right (24 December 2008 10:00 UTC) is an example of weak nucleation. The lower left (1 February 2009 10:00 UTC) shows strong nucleation events over Ukraine and western Russia, whereas western Europe is without events. Almost the opposite is seen in the lower centre (21 April 2009 12:00 UTC) panel, where 


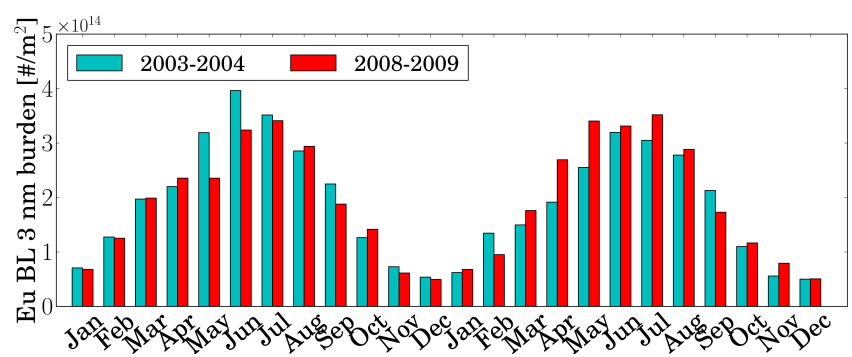

Figure 11. Monthly nucleated $3 \mathrm{~nm}$ particle burden calculated only for the boundary layer.

eastern Europe is without nucleation, but western and central Europe are experiencing a strong nucleation event. The last panel on the lower right (16 September 2009 12:00 UTC) shows a situation where central Europe is without nucleation, but western and eastern Europe are having events. These plots show that the nucleation events in the model can go from very local scales to hundreds of kilometres, which is in good agreement with previous studies of the spatial extent of nucleation (for example, over North America by Crippa and Pryor, 2013).

\subsection{Boundary layer analysis}

Using the information of the mean nucleation event length, the number of nucleation days per year and the mean formation rate from Hamed et al. (2007), combined with the height information of a well-mixed boundary layer from Laaksonen et al. (2005), a rough estimate of the yearly number of nucleated $3 \mathrm{~nm}$ particles in the boundary layer over San Pietro Capofiume can be calculated: $3.6 \times 10^{15} \mathrm{~m}^{-2}$. The equivalent value can be calculated from the model output for the grid box where San Pietro Capofiume is located without any estimations. The results are in Table 2, where the values for San Pietro Capofiume and Europe (only land points) are shown.

The values for San Pietro Capofiume are lower than the literature estimate. However, the difference is less than a factor of 2. Both the model and the literature estimates, especially the latter, have a number of possible (unquantified) error sources; therefore, such a difference appears quite reasonable.

The monthly production of $3 \mathrm{~nm}$ particles in the European boundary layer is shown in Fig. 11. The production has a minimum during the winter and a maximum during the summer. This shows that, overall, the simulated annual cycle of nucleation in the European boundary layer is more similar to that observed in San Pietro Capofiume (summer maximum, winter minimum Hamed et al., 2007) than the cycle in Hyytiälä (spring and autumn maxima Kulmala et al., 2004).
Table 2. Annual production of nucleated $3 \mathrm{~nm}$ particles in the boundary layer.

\begin{tabular}{ccc}
\hline Year & $\begin{array}{c}\text { San Pietro Capofiume } \\
{\left[\mathrm{m}^{-2}\right]}\end{array}$ & $\begin{array}{c}\text { Europe (land points) } \\
{\left[\mathrm{m}^{-2}\right]}\end{array}$ \\
\hline 2003 & $2.4 \times 10^{15}$ & $2.0 \times 10^{15}$ \\
2004 & $2.1 \times 10^{15}$ & $1.7 \times 10^{15}$ \\
2008 & $2.3 \times 10^{15}$ & $1.9 \times 10^{15}$ \\
2009 & $2.3 \times 10^{15}$ & $1.9 \times 10^{15}$ \\
\hline
\end{tabular}

\section{Conclusions}

A measurement-based $\mathrm{OH}$ proxy was implemented in the regional aerosol-climate model REMO-HAM. This supersedes a former version that used monthly mean fields for $\mathrm{OH}$ with an artificial diurnal cycle. The newly implemented proxy is a function of radiation, thus linking the cloudiness of the model to the $\mathrm{OH}$ concentrations. In addition, the nucleation rate expression was changed to directly calculate the $3 \mathrm{~nm}$ particles (in diameter).

Despite some underestimation in different regions, the new model version gives more realistic nucleation rates for $3 \mathrm{~nm}$ particles compared to the original model version, which overestimated the observed nucleation rates. Overall, the agreement with observations has been considerably improved.

Nucleation event statistics were analysed at 13 different European sites. The results show good agreement at some sites, but for some the yearly cycle was not captured. Also, for many (northern) sites, the OH-proxy model fails to predict nucleation events during autumn, whereas they are frequently observed. A more detailed analysis was done for three measurement sites (Hyytiälä, Melpitz and San Pietro Capofiume). The results show that the monthly means for start time, end time and length of nucleation events are quite well captured. The main problem is that the nucleation in the model tends to continue longer than in observations. The main reason for this can be the missing organic growth of particles, which leads to lower number concentration of particles $>100 \mathrm{~nm}$. This decreases the condensation sink of sulfuric acid and the remaining sulfuric acid will keep the nucleation active for longer period of time.

The vertical extension of nucleation events was also analysed. As expected, the events mainly happen inside the boundary layer. Because of the simple form of the proxy, the model simulates nucleation also in the upper troposphere. On the other hand, this feature has been reported also in earlier versions and in the global model ECHAM-HAM (Kazil et al., 2010; Pietikäinen et al., 2012). The distribution plots show that nucleation bursts are realistically captured, but the growth to larger particles is not as continuous as in measurements due to the missing organic condensation and the structure of the modal aerosol model (Korhola et al., 2013). 
The spatial distribution of nucleation events showed that strongest events occur close to the major sources of sulfur dioxide. It is worth noting that large point sources of $\mathrm{SO}_{2}$, such as in adjacent East European countries, seem to contribute to the strong nucleation events happening at Melpitz. Seasonally, the trend over Europe is to have strong nucleation during the summer and less during the winter. The same was shown when the total nucleation was calculated in the European boundary layer.

Small changes in the simple chemistry module can lead to big improvements in results, as is shown in this study. In addition, using a proxy does not increase the computational burden of the model at all. This makes the approach very useful in aerosol-climate models. To improve the system, more work should be targeted to connect the coefficients used in the proxy with regional features. This could mean, for example, two-dimensional maps for the coefficients. Also, taking into account the seasonal effects, the proxy could provide even more realistic results; this will be studied in a subsequent analysis. The same applies also for the nucleation coefficient (activation/kinetic). The regional meteorological and chemical features play an important role in shaping the nucleation events.

Acknowledgements. This work was supported by the Academy of Finland (Research Programme for Climate Change FICCA, project 140748, and the Center of Excellence Programme, project 1118615), by the strategic funding of the University of Eastern Finland, and by the EU FP7 IP PEGASOS (FP7-ENV-2010/265148). The authors would like to thank T. Nieminen for providing the Hyytiälä event classification data and Declan O'Donnell for proofreading and correcting the English language.

Edited by: E. Nemitz

\section{References}

Andreae, M. O.: The aerosol nucleation puzzle, Science, 339, 6122, 911-912, doi:10.1126/science.1233798, 2013.

Birmili, W. and Wiedensohler, A.: New particle formation in the continental boundary layer: meteorological and gas phase parameter influence, Geophys. Res. Lett., 27, 3325-3328, 2000.

Birmili, W., Berresheim, H., Plass-Dülmer, C., Elste, T., Gilge, S., Wiedensohler, A., and Uhrner, U.: The Hohenpeissenberg aerosol formation experiment (HAFEX): a long-term study including size-resolved aerosol, $\mathrm{H}_{2} \mathrm{SO}_{4}, \mathrm{OH}$, and monoterpenes measurements, Atmos. Chem. Phys., 3, 361-376, doi:10.5194/acp-3-361-2003, 2003.

Boulon, J., Sellegri, K., Venzac, H., Picard, D., Weingartner, E., Wehrle, G., Collaud Coen, M., Bütikofer, R., Flückiger, E., Baltensperger, U., and Laj, P.: New particle formation and ultrafine charged aerosol climatology at a high altitude site in the Alps (Jungfraujoch, $3580 \mathrm{~m}$ a.s.l., Switzerland), Atmos. Chem. Phys., 10, 9333-9349, doi:10.5194/acp-10-9333-2010, 2010.
Boulon, J., Sellegri, K., Hervo, M., Picard, D., Pichon, J.-M., Fréville, P., and Laj, P.: Investigation of nucleation events vertical extent: a long term study at two different altitude sites, Atmos. Chem. Phys., 11, 5625-5639, doi:10.5194/acp-11-56252011, 2011.

Crippa, P. and Pryor, S. C.: Spatial and temporal scales of new particle formation events in eastern North America, Atmos. Environ., 75, 257-264, 2013.

Dal Maso, M., Kulmala, M., Riipinen, I., Wagner, R., Hussein, T., Aalto, P., and Lehtinen, K. E. J.: Formation and growth of fresh atmospheric aerosols: eigth years of aerosol size distribution data from SMEAR II, Hyytiälä, Finland, Boreal Environ. Res., 10, 323-336, 2005.

Dal Maso, M., Sogacheva, L., Aalto, P. P., Riipinen, I., Komppula, M., Tunved, P., Korhonen, L., Suur-uski, V., Hirsikko, A., Kurtén, T., Kerminen, V.-M., Lihavainen, H., Viisanen, Y., Hansson, H.-C., and Kulmala, M.: Aerosol size distribution measurements at four Nordic field stations: identification, analysis and trajectory analysis of new particle formation bursts, Tellus B, 59, 350-361, 2007.

Dee, D. P., Uppala, S. M., Simmons, A. J., Berrisford, P., Poli, P., Kobayashi, S., Andrae, U., Balmaseda, M. A., Balsamo, G., Bauer, P., Bechtold, P., Beljaars, A. C. M., van de Berg, L., Bidlot, J., Bormann, N., Delsol, C., Dragani, R., Fuentes, M., Geer, A. J., Haimberger, L., Healy, S. B., Hersbach, H., Hólm, E. V., Isaksen, L., Kållberg, P., Köhler, M., Matricardi, M., McNally, A. P., Monge-Sanz, B. M., Morcrette, J.-J., Park, B.K., Peubey, C., de Rosnay, P., Tavolato, C., Thépaut, J.-N., and Vitart, F.: The ERA-Interim reanalysis: configuration and performance of the data assimilation system, Q. J. Roy. Meteor. Soc., 137, 553-597, doi:10.1002/qj.828, 2011.

Dentener, F., Kinne, S., Bond, T., Boucher, O., Cofala, J., Generoso, S., Ginoux, P., Gong, S., Hoelzemann, J. J., Ito, A., Marelli, L., Penner, J. E., Putaud, J.-P., Textor, C., Schulz, M., van der Werf, G. R., and Wilson, J.: Emissions of primary aerosol and precursor gases in the years 2000 and 1750 prescribed data-sets for AeroCom, Atmos. Chem. Phys., 6, 43214344, doi:10.5194/acp-6-4321-2006, 2006.

Engler, C., Rose, D., Wehner, B., Wiedensohler, A., Brüggemann, E., Gnauk, T., Spindler, G., Tuch, T., and Birmili, W.: Size distributions of non-volatile particle residuals $\left(\mathrm{D}_{p}<800\right.$ $\mathrm{nm}$ ) at a rural site in Germany and relation to air mass origin, Atmos. Chem. Phys., 7, 5785-5802, doi:10.5194/acp-7-5785-2007, 2007.

Feichter, J., Kjellström, E., Rodhe, H., Dentener, F., Lelieveld, J., and Roelofs, G.-J.: Simulation of the tropospheric sulfur cycle in a global climate model, Atmos. Environ., 30, 1693-1707, 1996.

Fountoukis, C., Riipinen, I., Denier van der Gon, H. A. C., Charalampidis, P. E., Pilinis, C., Wiedensohler, A., O'Dowd, C., Putaud, J. P., Moerman, M., and Pandis, S. N.: Simulating ultrafine particle formation in Europe using a regional CTM: contribution of primary emissions versus secondary formation to aerosol number concentrations, Atmos. Chem. Phys., 12, 86638677, doi:10.5194/acp-12-8663-2012, 2012.

Hagemann, S.: An improved land surface parameter data set for global and regional climate models, MPI Report No. 336, Max Planck Institute for Meteorology, Hamburg, 28 pp., 2002.

Hamed, A., Joutsensaari, J., Mikkonen, S., Sogacheva, L., Dal Maso, M., Kulmala, M., Cavalli, F., Fuzzi, S., Fac- 
chini, M. C., Decesari, S., Mircea, M., Lehtinen, K. E. J., and Laaksonen, A.: Nucleation and growth of new particles in Po Valley, Italy, Atmos. Chem. Phys., 7, 355-376, doi:10.5194/acp7-355-2007, 2007.

Hamed, A., Birmili, W., Joutsensaari, J., Mikkonen, S., Asmi, A., Wehner, B., Spindler, G., Jaatinen, A., Wiedensohler, A., Korhonen, H., Lehtinen, K. E. J., and Laaksonen, A.: Changes in the production rate of secondary aerosol particles in Central Europe in view of decreasing $\mathrm{SO}_{2}$ emissions between 1996 and 2006, Atmos. Chem. Phys., 10, 1071-1091, doi:10.5194/acp-10-10712010, 2010.

Hari, P. and Kulmala, M.: Station for Measuring EcosystemAtmosphere Relations (SMEAR II), Boreal Environ. Res., 10, 315-322, 2005.

Hienola, A. I., Pietikäinen, J.-P., Jacob, D., Pozdun, R., Petäjä, T., Hyvärinen, A.-P., Sogacheva, L., Kerminen, V.-M., Kulmala, M., and Laaksonen, A.: Black carbon concentration and deposition estimations in Finland by the regional aerosol-climate model REMO-HAM, Atmos. Chem. Phys., 13, 4033-4055, doi:10.5194/acp-13-4033-2013, 2013.

Horowitz, L. W., Walters, S., Mauzerall, D. L., Emmons, L. K., Rasch, P. J., Granier, C., Tie, X., Lamarque, J.-F., Schultz, M. G., Tyndall, G. S., Orlando, J. J., and Brasseur, G. P.: A global simulation of tropospheric ozone and related tracers: description and evaluation of MOZART, version 2, J. Geophys. Res., 108, 4784, doi:10.1029/2002JD002853, 853, 2003.

Jaatinen, A., Hamed, A., Joutsensaari, J., Mikkonen, S., Birmili, W., Wehner, B., Spindler, G., Wiedensohler, A., Decesari, S., Mircea, M., Facchini, M. C., Junninen, H., Kulmala, M., Lehtinen, K. E. J., and Laaksonen, A.: A comparison of new particle formation events in the boundary layer at three different sites in Europe, Boreal Environ. Res., 14, 481-498, 2009.

Jacob, D.: A note to the simulation of the annual and inter-annual variability of the water budget over the Baltic Sea drainage basin, Meteorol. Atmos. Phys., 77, 61-73, 2001.

Jacob, D. and Podzun, R.: Sensitivity studies with the regional climate model REMO, Meteorol. Atmos. Phys., 63, 119-129, 1996.

Jung, J., Fountoukis, C., Adams, P. J., and and Pandis, S. N.: Simulation of in situ ultrafine particle formation in the eastern United States using PMCAMx-UF, J. Geophys. Res., 15, 03203, doi:10.1029/2009JD012313, 2010.

Kazil, J. and Lovejoy, E. R.: A semi-analytical method for calculating rates of new sulfate aerosol formation from the gas phase, Atmos. Chem. Phys., 7, 3447-3459, doi:10.5194/acp-7-3447-2007, 2007.

Kazil, J., Lovejoy, E. R., Barth, M. C., and O’Brien, K.: Aerosol nucleation over oceans and the role of galactic cosmic rays, Atmos. Chem. Phys., 6, 4905-4924, doi:10.5194/acp-6-4905-2006, 2006.

Kazil, J., Stier, P., Zhang, K., Quaas, J., Kinne, S., O’Donnell, D., Rast, S., Esch, M., Ferrachat, S., Lohmann, U., and Feichter, J.: Aerosol nucleation and its role for clouds and Earth's radiative forcing in the aerosol-climate model ECHAM5-HAM, Atmos. Chem. Phys., 10, 10733-10752, doi:10.5194/acp-1010733-2010, 2010.

Kerminen, V.-M. and Kulmala, M.: Analytical formulae connecting the "real" and the "apparent" nucleation rate and the nuclei number concentration for atmospheric nucleation events, J. Aerosol Sci., 33, 609-622, 2002.
Kerminen, V.-M., Lihavainen, H., Komppula, M., Viisanen, Y., and Kulmala, M.: Direct observational evidence linking atmospheric aerosol formation and cloud droplet activation, Geophys. Res. Lett., 32, L14803, doi:10.1029/2005GL023130, 2005.

Kokkola, H., Hommel, R., Kazil, J., Niemeier, U., Partanen, A.-I., Feichter, J., and Timmreck, C.: Aerosol microphysics modules in the framework of the ECHAM5 climate model - intercomparison under stratospheric conditions, Geosci. Model Dev., 2, 97-112, doi:10.5194/gmd-2-97-2009, 2009.

Korhola, T., Kokkola, H., Korhonen, H., Partanen, A.-I., Laaksonen, A., Lehtinen, K. E. J., and Romakkaniemi, S.: Reallocation in modal aerosol models: impacts on predicting aerosol radiative effects, Geosci. Model Dev., 7, 161-174, doi:10.5194/gmd7-161-2014, 2014.

Kotlarski, S.: A Subgrid Glacier Parameterisation for Use in Regional Climate Modelling, Ph.D. thesis, University of Hamburg, Max Planck Institute for Meteorology, Reports on Earth System Science, No. 42, 2007.

Kristensson, A., Dal Maso, M., Swietlicki, E., Hussein, T., Zhou, J., Kerminen, V., and Kulmala, M.: Characterization of new particle formation events at a background site in Southern Sweden: relation to air mass history, Tellus B, 60, doi:10.3402/tellusb.v60i3.16927, 2011.

Kuang, C., McMurry, P. H., McCormick, A. V., and Eisele, F. L.: Dependence of nucleation rates on sulfuric acid vapor concentration in diverse atmospheric locations, J. Geophys. Res., 113, 10209, doi:10.1029/2007JD009253, 2008.

Kulmala, M., Vehkamäki, H., Petäjä, T., Dal Maso, M., Lauri, A., Kerminen, V.-M., Birmili, W., and McMurry, P. H.: Formation and growth rates of ultrafine atmospheric particles: a review of observations, J. Aerosol Sci., 35, 143-176, 2004.

Kulmala, M., Lehtinen, K. E. J., and Laaksonen, A.: Cluster activation theory as an explanation of the linear dependence between formation rate of $3 \mathrm{~nm}$ particles and sulphuric acid concentration, Atmos. Chem. Phys., 6, 787-793, doi:10.5194/acp-6-787-2006, 2006.

Kulmala, M., Kontkanen, J., Junninen, H., Lehtipalo, K., Manninen, H. E., Nieminen, T., Petäjä, T., Sipilä, M., Schobesberger, S., Rantala, P., Franchin, A., Jokinen, T., Järvinen, E., Äijälä, M., Kangasluoma, J., Hakala, J., Aalto, P. P., Paasonen, P., Mikkilä, J., Vanhanen, J., Aalto, J., Hakola, H., Makkonen, U., Ruuskanen, T., Mauldin, R. L., Duplissy, J., Vehkamäki, H., Bäck, J., Kortelainen, A., Riipinen, I., Kurtén, T., Johnston, M. V. Smith, J. N., Ehn, M., Mentel, T. F., Lehtinen, K. E. J., Laaksonen, A., Keminen, V.-M., and Worsnop, D.: Direct observations of atmospheric aerosol nucleation, Science, 22, 911-912, 2013.

Laakso, L., Anttila, T., Lehtinen, K. E. J., Aalto, P. P., Kulmala, M., Hõrrak, U., Paatero, J., Hanke, M., and Arnold, F.: Kinetic nucleation and ions in boreal forest particle formation events, Atmos. Chem. Phys., 4, 2353-2366, doi:10.5194/acp-4-2353-2004, 2004.

Laakso, L., Merikanto, J., Vakkari, V., Laakso, H., Kulmala, M., Molefe, M., Kgabi, N., Mabaso, D., Carslaw, K. S., Spracklen, D. V., Lee, L. A., Reddington, C. L., and Kerminen, V.-M.: Boundary layer nucleation as a source of new CCN in savannah environment, Atmos. Chem. Phys., 13, 1957-1972, doi:10.5194/acp-13-1957-2013, 2013.

Laaksonen, A., Hamed, A., Joutsensaari, J., Hiltunen, L., Cavalli, F., Junkermann, W., Asmi, A., Fuzzi, S., and Facchini, M. C.: 
Cloud condensation nucleus production from nucleation events at a highly polluted region, Geophys. Res. Lett., 32, L06812, doi:10.1029/2004GL022092, 2005.

Lihavainen, H., Kerminen, V.-M., Komppula, M., Hatakka, J., Aaltonen, V., Kulmala, M., and Viisanen, Y.: Production of "potential" cloud condensation nuclei associated with atmospheric newparticle formation in northern Finland, J. Geophys. Res., 108, 4782, doi:10.1029/2003JD003887, D24, 2003.

Lohmann, U., Stier, P., Hoose, C., Ferrachat, S., Kloster, S., Roeckner, E., and Zhang, J.: Cloud microphysics and aerosol indirect effects in the global climate model ECHAM5-HAM, Atmos. Chem. Phys., 7, 3425-3446, doi:10.5194/acp-7-3425-2007, 2007.

Makkonen, R., Asmi, A., Korhonen, H., Kokkola, H., Järvenoja, S., Räisänen, P., Lehtinen, K. E. J., Laaksonen, A., Kerminen, V.M., Järvinen, H., Lohmann, U., Bennartz, R., Feichter, J., and Kulmala, M.: Sensitivity of aerosol concentrations and cloud properties to nucleation and secondary organic distribution in ECHAM5-HAM global circulation model, Atmos. Chem. Phys., 9, 1747-1766, doi:10.5194/acp-9-1747-2009, 2009.

Manninen, H. E., Nieminen, T., Asmi, E., Gagné, S., Häkkinen, S., Lehtipalo, K., Aalto, P., Vana, M., Mirme, A., Mirme, S., Hõrrak, U., Plass-Dülmer, C., Stange, G., Kiss, G., Hoffer, A., Törő, N., Moerman, M., Henzing, B., de Leeuw, G., Brinkenberg, M., Kouvarakis, G. N., Bougiatioti, A., Mihalopoulos, N., O'Dowd, C., Ceburnis, D., Arneth, A., Svenningsson, B., Swietlicki, E., Tarozzi, L., Decesari, S., Facchini, M. C., Birmili, W., Sonntag, A., Wiedensohler, A., Boulon, J., Sellegri, K., Laj, P., Gysel, M., Bukowiecki, N., Weingartner, E., Wehrle, G., Laaksonen, A., Hamed, A., Joutsensaari, J., Petäjä, T., Kerminen, V.-M., and Kulmala, M.: EUCAARI ion spectrometer measurements at 12 European sites - analysis of new particle formation events, Atmos. Chem. Phys., 10, 7907-7927, doi:10.5194/acp-10-79072010, 2010.

Matsui, H., Koike, M., Kondo, Y., Takegawa, N., Wiedensohler, A., Fast, J. D., and Zaveri, R. A.: Impact of new particle formation on the concentrations of aerosols and cloud condensation nuclei around Beijing, J. Geophys. Res., 116, D19208, doi:10.1029/2011JD016025, 2011.

Merikanto, J., Zapadinsky, E., Lauri, A., and Vehkamäki, H.: Origin of the failure of classical nucleation theory: incorrect description of the smallest clusters, Phys. Rev. Lett., 98, 145702, doi:10.1103/PhysRevLett.98.145702, 2007.

Merikanto, J., Spracklen, D. V., Mann, G. W., Pickering, S. J., and Carslaw, K. S.: Impact of nucleation on global CCN, Atmos. Chem. Phys., 9, 8601-8616, doi:10.5194/acp-9-8601-2009, 2009.

Metzger, A., Verheggen, B, Dommen, J., Duplissy, J., Prevota, A. S. H., Weingartner, E., Riipinen, I., Kulmala, M., Spracklen, D. V., Carslaw, K. S., and Baltensperger, U.: Evidence for the role of organics in aerosol particle formation under atmospheric conditions, Proceedings of the National Academy of Sciences, 107(15), 6646-6651, doi:10.1073/pnas.0911330107, 2010.

Mikkonen, S., Romakkaniemi, S., Smith, J. N., Korhonen, H., Petäjä, T., Plass-Duelmer, C., Boy, M., McMurry, P. H., Lehtinen, K. E. J., Joutsensaari, J., Hamed, A., Mauldin III, R. L., Birmili, W., Spindler, G., Arnold, F., Kulmala, M., and Laaksonen, A.: A statistical proxy for sulphuric acid concentration,
Atmos. Chem. Phys., 11, 11319-11334, doi:10.5194/acp-1111319-2011, 2011.

Modgil, M. S., Kumar, S., Tripathi, S. N., and Lovejoy, E. R.: A parameterization of ion-induced nucleation of sulphuric acid and water for atmospheric conditions, J. Geophys. Res., 110, D19205, doi:10.1029/2004JD005475, 2005.

Napari, I., Noppel, M., Vehkamäki, H., and Kulmala, M.: Parametrization of ternary nucleation rates for $\mathrm{H}_{2} \mathrm{SO}_{4}$ $\mathrm{NH}_{3}-\mathrm{H}_{2} \mathrm{O}$ vapors, J. Geophys. Res., 107, 4381, doi:10.1029/2002JD002132, 2002.

O’Dowd, C. D., Hämeri, K., Mäkelä, J., Väkeva, M., Aalto, P., de Leeuw, G., Kunz, G. J., Becker, E., Hansson, H.-C., Allen, A. G., Harrison, R. M., Berresheim, H., Kleefeld, C., Geever, M., Jennings, S. G., and Kulmala, M.: Coastal new particle formation: environmental conditions and aerosol physicochemical characteristics during nucleation bursts, J. Geophys. Res., 107, 8107, doi:10.1029/2000JD000206, 2002.

Petäjä, T., Mauldin, III, R. L., Kosciuch, E., McGrath, J., Nieminen, T., Paasonen, P., Boy, M., Adamov, A., Kotiaho, T., and Kulmala, M.: Sulfuric acid and $\mathrm{OH}$ concentrations in a boreal forest site, Atmos. Chem. Phys., 9, 7435-7448, doi:10.5194/acp9-7435-2009, 2009.

Pfeifer, S.: Modeling cold cloud processes with the regional climate model REMO, Ph.D. thesis, Reports on Earth System Science, Max Planck Institute for Meteorology, Hamburg, 2006.

Pierce, J. R. and Adams, P. J.: Uncertainty in global CCN concentrations from uncertain aerosol nucleation and primary emission rates, Atmos. Chem. Phys., 9, 1339-1356, doi:10.5194/acp-91339-2009, 2009.

Pierce, J. R., Chen, K., and Adams, P. J.: Contribution of primary carbonaceous aerosol to cloud condensation nuclei: processes and uncertainties evaluated with a global aerosol microphysics model, Atmos. Chem. Phys., 7, 5447-5466, doi:10.5194/acp-75447-2007, 2007.

Pietikäinen, J.-P., O’Donnell, D., Teichmann, C., Karstens, U., Pfeifer, S., Kazil, J., Podzun, R., Fiedler, S., Kokkola, H., Birmili, W., O’Dowd, C., Baltensperger, U., Weingartner, E., Gehrig, R., Spindler, G., Kulmala, M., Feichter, J., Jacob, D., and Laaksonen, A.: The regional aerosol-climate model REMOHAM, Geosci. Model Dev., 5, 1323-1339, doi:10.5194/gmd-51323-2012, 2012.

Pikridas, M., Riipinen, I., Hildebrandt, L., Kostenidou, E., Manninen, H., Mihalopoulos, N., Kalivitis, N., Burkhart, J. F., Stohl, A., Kulmala, M., Pandis, S. N.: New particle formation at a remote site in the eastern Mediterranean, J. Geophys. Res., 117, D12205, doi:10.1029/2012JD017570, 2012.

Pirjola, L., Lehtinen, K. E. J., Hansson, H.-C., and Kulmala, M.: How important is nucleation in regional/global modelling?, Geophys. Res. Lett., 31, L12109, doi:10.1029/2004GL019525, 2004.

Rechid, D.: Land Surface Scheme of REMO, Internal report, Max Planck Institute for Meteorology, Hamburg, 3 pp., available at: http://www.remo-rcm.de/fileadmin/user_upload/remo/ UBA/pdf/LandSurfaceScheme_REMO_short-summary.pdf (last access: 1 March 2014), 2009.

Roeckner, E., Arpe, K., Bengtsson, L., Christoph, M., Claussen, M., Dumenil, L., Esch, M., Schlese, U., and Schulzweida, U.: The atmospheric general circulation model ECHAM4: Model description and simulation of present-day climate, Max Planck Insti- 
tute for Meteorology report series, Hamburg, Germany, Report No. 218, 1996

Roeckner, E., Baeuml, G., Bonventura, L., Brokopf, R., Esch, M., Giorgetta, M., Hagemann, S., Kirchner, I., Kornblueh, L., Manzini, E., Rhodin, A., Schlese, U., Schulzweida, U., and Tompkins, A.: The atmospheric general circulation model ECHAM5. PART I: Model description, Max Planck Institute for Meteorology report series, Hamburg, Germany, Report No. 349, 2003.

Rohrer, F. and Berresheim, H.: Strong correlation between levels of tropospheric hydroxyl radicals and solar ultraviolet radiation, Nature, 442, 184-187, doi:10.1038/nature04924, 2006.

Scott, C. E., Rap, A., Spracklen, D. V., Forster, P. M., Carslaw, K. S., Mann, G. W., Pringle, K. J., Kivekäs, N., Kulmala, M., Lihavainen, H., and Tunved, P.: The direct and indirect radiative effects of biogenic secondary organic aerosol, Atmos. Chem. Phys., 14, 447-470, doi:10.5194/acp-14-447-2014, 2014.

Seinfeld, J. and Pandis, S.: Atmospheric Chemistry and Physics, John Wiley \& Sons inc., New York, 1998.

Semmler, T., Jacob, D., Schlünzen, K. H., and Podzun, R.: Influence of sea ice treatment in a regional climate model on boundary layer values in the Fram Strait region, Mon. Weather Rev., 132, 985-999, 2004.

Sihto, S.-L., Kulmala, M., Kerminen, V.-M., Dal Maso, M., Petäjä, T., Riipinen, I., Korhonen, H., Arnold, F., Janson, R., Boy, M., Laaksonen, A., and Lehtinen, K. E. J.: Atmospheric sulphuric acid and aerosol formation: implications from atmospheric measurements for nucleation and early growth mechanisms, Atmos. Chem. Phys., 6, 4079-4091, doi:10.5194/acp-64079-2006, 2006.

Sotiropoulou, R. E. P., Tagaris, E., Pilinis, C., Anttila, T., and Kulmala, M.: Modeling new particle formation during air pollution episodes: impacts on aerosol and cloud condensation nuclei, Aerosol Sci. Tech., 40, 557-572, 2006.

Spracklen, D. V., Carslaw, K. S., Kulmala, M., Kerminen, V.-M., Mann, G. W., and Sihto, S.-L.: The contribution of boundary layer nucleation events to total particle concentrations on regional and global scales, Atmos. Chem. Phys., 6, 5631-5648, doi:10.5194/acp-6-5631-2006, 2006.

Spracklen, D. V., Carslaw, K. S., Kulmala, M., Kerminen, V.-M., Sihto, S.-L., Riipinen, I., Merikanto, J., Mann, G. W., Chipperfield, M. P., Wiedensohler, A., Birmili, W., and Lihavainen, H.: The contribution of particle formation to global cloud condensation nuclei concentrations, Geophys. Res. Lett., 35, L06808, doi:10.1029/2007GL033038, 2008.
Stier, P., Feichter, J., Kinne, S., Kloster, S., Vignati, E., Wilson, J., Ganzeveld, L., Tegen, I., Werner, M., Balkanski, Y., Schulz, M., Boucher, O., Minikin, A., and Petzold, A.: The aerosol-climate model ECHAM5-HAM, Atmos. Chem. Phys., 5, 1125-1156, doi:10.5194/acp-5-1125-2005, 2005.

Trivitayanurak, W., Adams, P. J., Spracklen, D. V., and Carslaw, K. S.: Tropospheric aerosol microphysics simulation with assimilated meteorology: model description and intermodel comparison, Atmos. Chem. Phys., 8, 3149-3168, doi:10.5194/acp-8-3149-2008, 2008.

Vehkamäki, H., Kulmala, M., Napari, I., Lehtinen, K. E. J., Timmreck, C., Noppel, M., and Laaksonen, A.: An improved parameterization for sulfuric acid-water nucleation rates for tropospheric and stratospheric conditions, J. Geophys. Res., 107, 4622, doi:10.1029/2002JD002184, 2002.

Vignati, E., Wilson, J., and Stier, P.: M7: an efficient sizeresolved aerosol microphysics module for large-scale aerosol transport models, J. Geophys. Res., 109, D22202, doi:10.1029/2003JD004485, 2004.

Wang, M. and Penner, J. E.: Aerosol indirect forcing in a global model with particle nucleation, Atmos. Chem. Phys., 9, 239-260, doi:10.5194/acp-9-239-2009, 2009.

Yoon, Y. J., O’Dowd, C. D., Jennings, S. G., and Lee, S. H.: Statistical characteristics and predictability of particle formation events at Mace Head, J. Geophys. Res., 111, D13204, doi:10.1029/2005JD006284, 2006.

Yu, F. and Luo, G.: Simulation of particle size distribution with a global aerosol model: contribution of nucleation to aerosol and CCN number concentrations, Atmos. Chem. Phys., 9, 76917710, doi:10.5194/acp-9-7691-2009, 2009.

Yu, F.: Ion-mediated nucleation in the atmosphere: Key controlling parameters, implications, and look-up table, Journal of Geophysical Research: Atmospheres, 115, D3, 2156-2202, doi:10.1029/2009JD012630, 2010.

Zhang, K., O’Donnell, D., Kazil, J., Stier, P., Kinne, S., Lohmann, U., Ferrachat, S., Croft, B., Quaas, J., Wan, H., Rast, S., and Feichter, J.: The global aerosol-climate model ECHAM-HAM, version 2: sensitivity to improvements in process representations, Atmos. Chem. Phys., 12, 8911-8949, doi:10.5194/acp-12-8911-2012, 2012. 